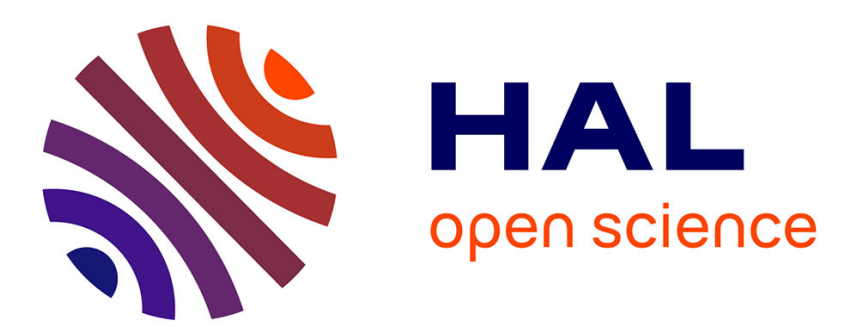

\title{
Global characterization of hydrodynamics and gas-liquid mass transfer in a thin-gap bubble column intended for microalgae cultivation
}

Charlène Thobie, Emilie Gadoin, W. Blel, Jeremy Pruvost, Caroline Gentric

\section{- To cite this version:}

Charlène Thobie, Emilie Gadoin, W. Blel, Jeremy Pruvost, Caroline Gentric. Global characterization of hydrodynamics and gas-liquid mass transfer in a thin-gap bubble column intended for microalgae cultivation. Chemical Engineering and Processing: Process Intensification, 2017, 122, pp.76-89. 10.1016/j.cep.2017.10.009 . hal-01923361

\section{HAL Id: hal-01923361 https://hal.science/hal-01923361}

Submitted on 20 Apr 2020

HAL is a multi-disciplinary open access archive for the deposit and dissemination of scientific research documents, whether they are published or not. The documents may come from teaching and research institutions in France or abroad, or from public or private research centers.
L'archive ouverte pluridisciplinaire HAL, est destinée au dépôt et à la diffusion de documents scientifiques de niveau recherche, publiés ou non, émanant des établissements d'enseignement et de recherche français ou étrangers, des laboratoires publics ou privés. 


\title{
Global characterization of hydrodynamics and gas-liquid mass transfer in a thin-gap bubble column intended for microalgae cultivation
}

\author{
Charlène Thobie, Emilie Gadoin, Walid Blel, Jérémy Pruvost, Caroline Gentric* \\ GEPEA, CNRS-UMR 6144, 37 Bd de l'Université, BP 406, 44602 Saint-Nazaire Cedex, France
}

\begin{abstract}
A B S T R A C T
Global characterization of hydrodynamics and gas-liquid transfer in a 2D column with a $4 \mathrm{~mm}$ thickness is carried out with water and aqueous glycerol solutions. This new design can be used as a photobioreactor of low thickness to intensify the volumetric productivity by increasing microalgae concentration. To mimic the presence of algae cultures, the liquid viscosity is adjusted with glycerol. Focuses are made on flow regimes and their transitions, mixing, and gas-liquid transfer at the scale of the reactor. In comparison with conventional bubble columns lower terminal velocities are obtained. So, in homogeneous regime, the residence time of bubbles is greater than in conventional bubble columns and the gas holdup is slightly higher. However, regime transitions appear at relatively low superficial gas velocities in the confined bubble column. In addition, two transition regimes are visible and have macroscopic flow structures very similar to the ones observed for conventional columns. For the mixing time, a dependence on the viscosity is observed and whatever the solution tested, this parameter decreases very quickly with the increase of the gas superficial velocity. Finally, global gas-liquid mass transfer coefficients measurements show lower values than in classical bubble columns at the same superficial gas velocity.
\end{abstract}

\section{Introduction}

Microalgae cultivation in photobioreactors (PBRs) is a process which becomes increasingly popular in recent years due to many potential fields of application (energy, green chemistry, food supplement, etc.). The use of photobioreactors of low thickness, i.e. of a few millimeters, allows to intensify the volumetric productivity by increasing microalgae concentration. Together with a reduction of the amount of water, this type of PBR allows diminishing the cultivation, mixing and harvesting costs $[1,2]$. Some technologies have already been proposed to meet the objective of high cell concentrations as the Algofilm $\left({ }^{(}\right)$ technology which is based on a falling film of small thickness moving on a smooth surface exposed to sunlight $[3,4]$ as well as vertical photobioreactors of small thickness, typically less than $7 \mathrm{~mm}$, operating as bubble columns [5]. Indeed, bubble columns or airlifts are commonly used as PBRs since they allow good mixing and ensure gas-liquid transfers necessary for the growth of microalgae. However, thin-gap bubble columns with high cell concentration can entail several problems such as reduced mixing capabilities, poor gas-liquid mass transfer or biofilm development [6].

Hydrodynamics in gas-liquid reactors is known for its complexity: bubbles deformability, break-up and coalescence phenomena, existence of various flow regimes which are not easy to predict. In fact, it was shown in previous studies that two-phase flow behavior is strongly dependent on physico-chemical properties of the fluids $[7,8]$ on the reactor and sparger geometries [9-11] and on the operating conditions [12-16]. In spite of this complexity, experimental and numerical studies of airlifts or bubble columns in standard operating conditions (Newtonian liquid phase, no confinement, low pressure and temperature...) allow at present a good characterization of hydrodynamics [17] and satisfactory predictions of the flow behavior [18-20]. Three main flow regimes have been identified in classical bubble columns $[21,22,9,17,20]$. The homogeneous regime is characterized by small bubbles that rise vertically without interacting with each other. This regime occurs when the superficial gas velocity is low [21] and the gas is uniformly injected into the column $[22,23]$. When the gas superficial velocity increases with uniform aeration, the transition regime appears $[9,24]$. This regime is characterized by the appearance of a polydisperse population of bubbles since coalescence and break-up phenomena become significant. The heterogeneous regime appears at the highest superficial gas velocities when the flow becomes unstable $[21,22,19]$. When the gas distribution is non-uniform, the heterogeneous regime is observed regardless of the gas flowrate. This regime is characterized by a wide distribution of bubble sizes. Being able to characterize and

\footnotetext{
* Corresponding author.

E-mail address: caroline.gentric@univ-nantes.fr (C. Gentric).
} 


\begin{tabular}{|c|c|c|c|}
\hline \multicolumn{2}{|c|}{ Nomenclature } & $\mathrm{P}_{\mathrm{atm}}$ & Atmospheric pressure $(\mathrm{Pa})$ \\
\hline $\mathrm{C}_{0}$ & Initial concentration of $\mathrm{O}_{2}\left(\mathrm{~kg} \mathrm{~m}^{-3}\right)$ & $\mathrm{P}_{\mathrm{CO} 2}$ & Carbon dioxide volumetric consumption $\left(\mathrm{kg} \mathrm{m}^{-3} \mathrm{~s}^{-1}\right)$ \\
\hline$C^{*}$ & $\begin{array}{l}\text { Saturated concentration of dissolved oxygen or carbon } \\
\text { dioxide }\left(\mathrm{kg} \mathrm{m}^{-3}\right)\end{array}$ & $\begin{array}{l}\mathrm{P}_{\mathrm{X}} \\
\mathrm{T}\end{array}$ & $\begin{array}{l}\text { Biomass volumetric productivity }\left(\mathrm{kg} \mathrm{m}^{-3} \mathrm{~s}^{-1}\right) \\
\text { Temperature }\left({ }^{\circ} \mathrm{C}\right)\end{array}$ \\
\hline $\mathrm{C}$ & $\begin{array}{l}\text { Instantaneous concentration of } \mathrm{O}_{2} \text { measured by } \mathrm{O}_{2} \text { probe } \\
\left(\mathrm{kg} \mathrm{m}^{-3}\right)\end{array}$ & $\begin{array}{l}\mathrm{t} \\
\mathrm{t}_{\mathrm{m}}\end{array}$ & $\begin{array}{l}\text { Time (s) } \\
\text { Mixing time (s) }\end{array}$ \\
\hline $\mathrm{C}_{\mathrm{O} 2}$ & Dissolved oxygen concentration $\left(\mathrm{kg} \mathrm{m}^{-3}\right)$ & $t_{\exp }$ & Exposure time (Higbie) (s) \\
\hline $\mathrm{C}_{\mathrm{CO} 2}$ & Dissolved carbon dioxide concentration $\left(\mathrm{kg} \mathrm{m}^{-3}\right)$ & $\mathrm{U}_{\mathrm{Gsup}}$ & Superficial gas velocity $\left(\mathrm{m} \mathrm{s}^{-1}\right)$ \\
\hline$d_{b}$ & Bubble diameter $(\mathrm{m})$ & $\mathrm{U}_{\text {swarm }}$ & Swarm velocity $\left(\mathrm{m} \mathrm{s}^{-1}\right)$ \\
\hline $\mathrm{D}_{\mathrm{c}}$ & Column diameter $(\mathrm{m})$ & $\mathrm{U}_{\infty}$ & Terminal velocity of bubble $\left(\mathrm{m} \mathrm{s}^{-1}\right)$ \\
\hline $\mathrm{D}_{\mathrm{L}}$ & Diffusion coefficient $\left(\mathrm{m}^{2} \mathrm{~s}^{-1}\right)$ & $\mathrm{V}_{\mathrm{G}}$ & Volume of the gas phase $\left(\mathrm{m}^{3}\right)$ \\
\hline $\mathrm{D}_{\mathrm{O} 2}$ & Dioxygen diffusion coefficient $\left(\mathrm{m}^{2} \mathrm{~s}^{-1}\right)$ & $\mathrm{V}_{\mathrm{L}}$ & Volume of the liquid phase $\left(\mathrm{m}^{3}\right)$ \\
\hline $\mathrm{D}_{\mathrm{CO} 2}$ & Carbon dioxyde diffusion coefficient $\left(\mathrm{m}^{2} \mathrm{~s}^{-1}\right)$ & $\mathrm{y}_{\mathrm{CO} 2}$ & Molar fraction of $\mathrm{CO}_{2}$ in the air \\
\hline$g$ & Gravity acceleration $\left(\mathrm{m} \mathrm{s}^{-2}\right)$ & $\mathrm{Y}_{\mathrm{O} 2 / \mathrm{X}}$ & Specific yield of oxygen production $\left(\mathrm{kg}_{\mathrm{O} 2} / \mathrm{kg}_{\text {biomass }}\right)$ \\
\hline $\mathrm{H}$ & Henry's constant $\left(\mathrm{Pa} \mathrm{m}^{3} \mathrm{~kg}^{-1}\right)$ & $\mathrm{Y}_{\mathrm{X} / \mathrm{CO} 2}$ & Specific yield of biomass production ( $\mathrm{kg}_{\text {biomass }} / \mathrm{kg}_{\mathrm{CO} 2}$ ) \\
\hline $\mathrm{H}_{\mathrm{L}}$ & Liquid height in the bubble column (without bubble) (m) & $\varepsilon_{\mathrm{G}}$ & Global gas holdup \\
\hline$<\mathrm{j}_{\mathrm{GL}}$ & & $\mu$ & Fluid viscosity (Pa s) \\
\hline$>$ & Drift flux $\left(\mathrm{m} \mathrm{s}^{-1}\right)$ & $\rho_{\mathrm{G}}$ & Gas density $\left(\mathrm{kg} \mathrm{m}^{-3}\right)$ \\
\hline $\mathrm{k}_{\mathrm{L}} \mathrm{a}$ & Volumetric gas-liquid mass transfer coefficient $\left(\mathrm{s}^{-1}\right)$ & $\rho_{\mathrm{L}}$ & Liquid density $\left(\mathrm{kg} \mathrm{m}^{-3}\right)$ \\
\hline $\mathrm{N}_{\mathrm{O} 2}$ & Oxygen mass transfer rate $\left(\mathrm{kg} \mathrm{m}^{-3} \mathrm{~s}^{-1}\right)$ & $\sigma$ & Surface tension $\left(\mathrm{N} \mathrm{m}^{-1}\right)$ \\
\hline $\mathrm{N}_{\mathrm{CO} 2}$ & Carbon dioxide mass transfer rate $\left(\mathrm{kg} \mathrm{m}^{-3} \mathrm{~s}^{-1}\right)$ & $\tau_{\mathrm{O} 2}$ & Characteristic time of gas transfer (s) \\
\hline
\end{tabular}

predict the hydrodynamic behavior of a gas-liquid reactor is of crucial importance since transfer characteristics may strongly differ from one regime to another. According to Deckwer [21], it is preferable to operate gas-liquid reactors in homogeneous regime, because the volumetric absorption coefficient $\mathrm{k}_{\mathrm{L}} \mathrm{a}$ is greater than in the heterogeneous one: the higher mass transfer coefficient $\mathrm{k}_{\mathrm{L}}$ due to improved mixing in heterogeneous conditions does not compensate the decrease in the interfacial area. One classical method to determine the regime

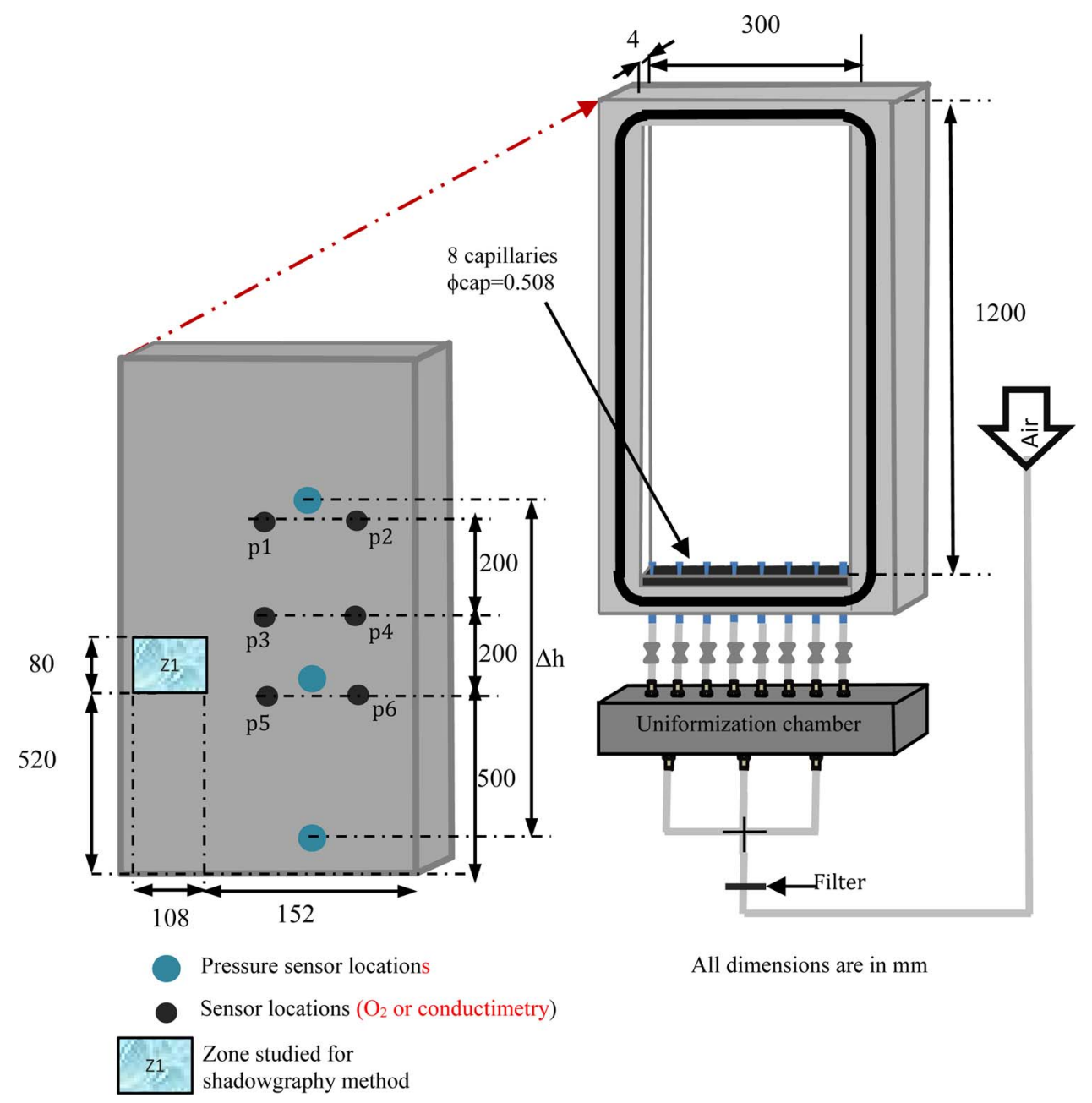

Fig. 1. Thin-gap confined bubble column (dimensions in $\mathrm{mm}$ ). 
Table 1

Physical properties of the liquid phases.

\begin{tabular}{|c|c|c|c|c|}
\hline Fluids & $\rho\left(\mathrm{kg} \mathrm{m}^{-3}\right)$ & $\mu \times 10^{3}(\mathrm{~Pa} \mathrm{~s})$ & $\begin{array}{l}\sigma \times 10^{3} \\
\left(\mathrm{~N} \mathrm{~m}^{-1}\right)\end{array}$ & $\mathrm{T}\left({ }^{\circ} \mathrm{C}\right)$ \\
\hline Demineralized water & $999 \pm 1$ & $1.00 \pm 0.01$ & $72.7 \pm 1.0$ & 20 \\
\hline $\begin{array}{l}10 \% \mathrm{w} / \mathrm{w} \text { glycerol } \\
\text { solution }\end{array}$ & $1017 \pm 1$ & $1.46 \pm 0.01$ & $69.5 \pm 1.0$ & 20 \\
\hline $\begin{array}{l}50 \% \mathrm{w} / \mathrm{w} \text { glycerol } \\
\text { solution }\end{array}$ & $1120 \pm 1$ & $5.66 \pm 0.05$ & $61.4 \pm 2.7$ & 20 \\
\hline Culture medium & $997 \pm 1$ & $1.00 \pm 0.01$ & $62.0 \pm 1.8$ & 25 \\
\hline $\begin{array}{l}\text { Chlorella Vulgaris culture } \\
\text { at } 3 \mathrm{~g} / \mathrm{L}\end{array}$ & & $1.35 \pm 0.01$ & & 25 \\
\hline
\end{tabular}

transitions consists in locating the slope changes of the average gas holdup $v s$ gas superficial velocity plot $[17,21,12]$. Other methods are also widely used in the literature: the swarm velocity method $[14,16,25]$ developed by Zuber and Findlay [26] and the drift-flux method [12,27] of Wallis [28].

The characterization of gas-liquid hydrodynamics in 2D confined geometries has been little addressed in the literature. However, it is expected that specific characteristics will be observed due to bubbles motion becoming essentially 2-dimensional, decreased turbulence production, increased bubbles/walls interactions. A local characterization of the hydrodynamics of such contactors has already been carried out in the literature for a $1 \mathrm{~mm}$ thick 2D column $[29,30]$. The hydrodynamics of an isolated bubble as well as the velocity field of the liquid phase in its vicinity were characterized by shadowgraphy and particle image velocimetry (PIV) [29,30]. Gas-liquid mass transfer was also studied for an isolated oxygen bubble using a planar laser induced fluorescence (PLIF) technique [31]. Then the dynamics of a swarm of bubbles was studied by shadowgraphy [32]. These studies showed a 2D dynamics, widely different from the conventional 3D one, with a particular role of the liquid films developed between the bubble and the walls, which generate increased friction forces.

Moreover, it must be pointed out that in the context of intensified microalgae cultivation, another phenomenon is observed, i.e. an increase of the continuous phase viscosity appears due to higher cell concentration; non-Newtonian behavior has even been observed for the highest concentrations [6].

The purpose of the present study is to investigate global characteristics of hydrodynamics and gas-liquid transfer in a thin-gap bubble column with a $4 \mathrm{~mm}$ thickness. A cold flow bubble column is considered here with water or glycerol aqueous solutions as the liquid phase and air as the gas phase. Glycerol concentration is adjusted to mimic the viscosity of increasing microalgae concentrations. Focuses are made on flow regimes and flow regime transitions, mixing performances, and gas-liquid transfer at the scale of the reactor. In fact, it is important to be able to predict flow regimes which will depend on the operating conditions, and will govern mixing and transfer characteristics of the reactor. Mixing capabilities are crucial since even distribution of all the nutrients is necessary for optimal microalgae growth. Mixing also prevents the microorganisms sedimentation. The liquid phase mixing is due to various processes like transport in the bubble wakes and macro-circulations due to differences in gas holdup at the scale of the reactor [33]. Another important characteristic of bioreactors is the gas-liquid mass transfer of $\mathrm{O}_{2}$ for aerobic cultures or of $\mathrm{CO}_{2}$ for photobioreactors. Gas-liquid transfer is all the more important for intensified PBRs since it is critical that $\mathrm{CO}_{2}$ supply is not limiting at high cell concentration. Global gas holdup, mixing time and global $\mathrm{k}_{\mathrm{L}}$ a measurements are thus performed. A whole range of superficial gas velocities covering different flow regimes and three liquid phase viscosities are considered. Characteristics are compared to literature results for conventional bubble columns in order to put into evidence specific hydrodynamics and mass transfer characteristics induced by confinement.

\section{Materials and methods}

\subsection{Experimental set-up and fluid characteristics}

The experimental set-up consists in a thin-gap parallelepipedic bubble column $(0.004 \mathrm{~m} * 1.2 \mathrm{~m} * 0.3 \mathrm{~m})$ made with transparent poly (methyl methacrylate) (Fig. 1). Gas sparging is performed through 8 capillaries of $0.508 \mathrm{~mm}$ inner diameter uniformly distributed at the bottom of the column. Before entering these capillaries, gas passes through a calming chamber allowing all the needles to be uniformly supplied by gas. The range of considered superficial gas velocities is [0.003-0.066] $\mathrm{m} \mathrm{s}^{-1}$ and allows to cover all flow regimes. A mass flowmeter/controller (EL-FLOW ${ }^{\circ}$-BRONKHORST ${ }^{\circ}$ ) is used to control and regulate the gas flow rate. Unless otherwise stated, gas consists in filtered compressed air. The unaerated liquid level in the reactor is fixed at $0.95 \mathrm{~m}$ for all experiments. Two pressure sensors (KELLER PR25) are used to determine the global gas holdup; they can be positioned at three heights as presented in Fig. 1. The front wall of the column also possesses six locations ( $\mathrm{p} 1$ to $\mathrm{p} 6$ in Fig. 1) which can be used to introduce conductivity or $\mathrm{O}_{2}$ sensors. p1, p3 and p5 are located at the middle width of the bubble column whereas $\mathrm{p} 2, \mathrm{p} 4$ and $\mathrm{p} 6$ lie at $1 / 6$ width. In the vertical direction, the sensors can be put at $900 \mathrm{~mm}, 700 \mathrm{~mm}$ and $500 \mathrm{~mm}$ from the bottom, respectively for p1-p2, p3-p4 and p5-p6.

The column hydrodynamics is characterized with three possible liquid phases, i.e. demineralized water, $10 \% \mathrm{w} / \mathrm{w}$ and $50 \% \mathrm{w} / \mathrm{w}$ aqueous solutions of glycerol. A Milli-Q Advantage A10 ${ }^{\circ}$ is used to provide ultrapure water (conductivity $<0.1 \mu \mathrm{S} / \mathrm{cm}$ ). The physico-chemical properties of the considered liquid phases are given in Table 1 . The aim is to mimic Chlorella vulgaris cultures of increasing concentrations. In fact, Soulies et al. have shown that Chlorella vulgaris cultures have a Newtonian behavior until a dry biomass concentration of $30 \mathrm{gL}^{-1}$ which corresponds to a cell volume fraction of 0.115 [6]. In the Newtonian domain, the viscosity increases with the cell volume fraction following the Quemada model. For intermediate values of the cell volume fraction, between 0.115 and 0.25 , the rheological behavior becomes shear thinning, whereas for the highest volume fractions $(>0.25)$, an apparent yield stress regime is observed. In the present study, it was chosen to investigate the influence of viscosity for a liquid phase presenting a Newtonian behavior only. All viscosities have been measured using a coaxial cylinder rheometer (Physica MCR500). The viscosity of the culture medium is close to the one of water, i.e. 1.0 mPa.s at $25^{\circ} \mathrm{C}$. The viscosity of a solution of Chlorella vulgaris of about $3 \mathrm{gL}^{-1}$ of dry matter coming from a conventional airlift photobioreactor has also been measured: it is equal to $1.35 \mathrm{mPa}$.s at $25^{\circ} \mathrm{C}$, the cultivation temperature. The glycerol aqueous solutions have a Newtonian behavior, their viscosities have been measured at $20^{\circ} \mathrm{C}$ since the cold-flow experiments are performed at $20^{\circ} \mathrm{C}$; their values are equal to 1.46 and $5.66 \mathrm{mPa}$.s respectively for 10 and $50 \% \mathrm{w} / \mathrm{w}$ solutions. Those values would correspond to dry weight biomass concentrations of 30 and $92 \mathrm{~g} \mathrm{~L}^{-1}$ respectively, i.e. cell volume fractions of 12 and $37 \%$ [6]- it can be noticed that in this last case, for a real algal suspension, the behavior would not be Newtonian anymore.

The surface tensions are measured with the drop shape analyzer Krüss-DSA30 using the pendant drop method [34]; results are also reported in Table 1.

\subsection{Methods}

\subsubsection{Bubble size and velocity estimations by shadowgraphy}

Size and instantaneous velocity of bubbles are estimated by a shadowgraphy method using the DANTEC DYNAMICS ShadowStrobe. This method is based on high resolution imaging with backlight illumination. A pulsed laser system is used to illuminate an optical fiber delivering extremely short light pulses from a few nanoseconds to hundreds of nanoseconds. To have a uniform bright illumination, the ShadowStrobe and the camera are aligned in the same optical axis. In 
this study, a CCD camera (Flow Sense M3/E 8 bits) is used. The camera is equipped with a fixed focal lens of $60 \mathrm{~mm}$ with a variable aperture from 2.3 to 32 , its resolution is $1600 \times 1186$ pixels with a maximum frequency of $15 \mathrm{~Hz}$; acquisition is synchronized with laser pulses. During all acquisitions, the imaging frequency is taken at its maximum value.

A shadowgraphy image of a single bubble - injected with a syringe connected to one capillary - rising in the column is presented in Fig. 2. The zone studied - denoted z1 in Fig. 1- is located at $52 \mathrm{~cm}$ from the bottom. Its height is $8 \mathrm{~cm}$ and its width $10.8 \mathrm{~cm}$. The Dantec Dynamic Studio Shadow Sizer then allows measuring size, shape and velocity of the registered bubbles. The threshold level is the main parameter that helps defining the contours of the bubbles on the images. For each detected bubble, the image analysis estimates the projected area on a vertical plane. Then the equivalent diameter $d_{b}$ corresponds to the diameter of a spherical bubble having the same projected area as the measured bubble. It must be pointed out that, in the case of large bubbles which are flattened in the column gap - typically bubbles with equivalent diameters $>4 \mathrm{~mm}-$ it results in an overestimation of their volume real equivalent diameter.

The horizontal and vertical components of the bubble velocity (respectively $\mathrm{u}$ and $\mathrm{v}$ ) are determined as the horizontal and vertical displacements between two frames divided by the time between two laser pulses. Then, the velocity of the single bubble rising in the column is determined by the relation $\left(U=\sqrt{v^{2}+u^{2}}\right)$. This velocity is averaged over several images (between 5 and 10).

The same method is used for swarms of bubbles. For each class of bubble size, the mean velocity is calculated as well as the Sauter diameter $\left(\mathrm{d}_{32}\right)$ which is defined as the diameter of a sphere having the same volume to surface ratio as the bubbles it represents:

$d_{32}=d_{\text {Sauter }}=\frac{\sum_{i=1}^{n} d_{i}{ }^{3} n_{i}}{\sum_{i=1}^{n} d_{i}{ }^{2} n_{i}}$

where $d_{i}$ and $n_{i}$ are respectively the bubble diameter and the number of bubbles of class $i$.

Only the homogeneous and transition regimes are considered here since in the heterogeneous regime, some bubbles are larger than the measurement window and cannot be accounted for with our shadowgraphy technique. When the bubble diameter is less or around $4 \mathrm{~mm}$ (column thickness) the bubble volume is fairly well estimated. If its measured diameter becomes greater than $4 \mathrm{~mm}$, it will be flattened. In that case, the bubble volume is calculated as the one of a flat cylinder.

\subsubsection{Gas holdup}

The global gas holdup $\left(\varepsilon_{\mathrm{G}}\right)$ can be defined as the ratio of the gas volume to the total volume:

$\varepsilon_{G}=\frac{V_{G}}{V_{G}+V_{L}}$

where $\mathrm{V}_{\mathrm{G}}$ et and $\mathrm{V}_{\mathrm{L}}$ correspond to the volumes of the gas and the liquid phases respectively. The gas holdup is an important parameter influencing mixing and mass transfer [35]. Besides, it is often used to determine the flow regimes $[14,16,25]$. Two methods can be used to estimate the global gas holdup: height difference measurement [36] and differential pressure measurement [37-40]. With the height difference method, the global gas holdup is determined from the height of the unaerated liquid and the total height under aeration. These parameters are determined visually, thus the aerated height is submitted to significant uncertainty because of oscillations of the free surface, especially at high gas flowrate. Therefore, the differential pressure method is used for this study. The global gas holdup can then be given by Eq. (3), by assuming that the wall-friction and the acceleration contributions in momentum balance are negligible and considering that $\rho_{\mathrm{G}}<<\rho_{\mathrm{L}}$ :
$\varepsilon_{G}=1-\frac{\Delta P}{\rho_{L} g \Delta h}$

where $\Delta \mathrm{P}$ is the differential pressure between the two pressure sensors. Here, they are located at heights of respectively $20 \mathrm{~mm}$ and $950 \mathrm{~mm}$ from the bottom of the reactor (Fig. 1). $\Delta \mathrm{h}$ is the distance between these two locations. Experiments are performed using a piezoelectric pressure sensor (KELLER-PR25) with a measuring range of -200 to $200 \mathrm{mbar}$ and an accuracy of $\pm 0.2 \%$. Averaged values of pressure are considered; they are calculated over $300 \mathrm{~s}$ with an acquisition frequency of $50 \mathrm{~Hz}$.

\subsubsection{Transitions between regimes}

The first method to determine the transitions between regimes is to study the evolution of the global gas holdup $v s$ superficial gas velocity and to determine changes in the slope $[17,21]$. However transitions can be difficult to identify when the slope changes gradually [41].

The second method was developed by Zuber and Findlay [26] and is based on the swarm velocity, $\mathrm{U}_{\mathrm{swarm}}$, which corresponds to the ratio between the superficial gas velocity, $\mathrm{U}_{\mathrm{Gsup}}$ and the global gas holdup $\varepsilon_{\mathrm{G}}$ :

$U_{\text {swarm }}=\frac{U_{G s u p}}{\varepsilon_{G}}$

When the swarm velocity is plotted $v s$ superficial gas velocity, the swarm velocity is constant during homogeneous regime and increases when the heterogeneous regime begins. In fact, the appearance of large bubbles with lower residence time entails an increase in the swarm velocity $[14,16,25]$. The third method to identify transitions between regimes is the drift-flux method developed by Wallis [28]. Its principle has been largely developed in the literature [25]. The drift flux < $j_{G L}>$ represents the volumetric flux of one phase relative to a surface moving at the average velocity. In our case, since the bubble column is closed to the liquid phase (i.e. no liquid is brought or removed continuously into the column), the liquid superficial velocity is equal to zero and the drift flux can be simplified as:

$\left\langle j_{G L}\right\rangle=U_{G s u p} *\left(1-\varepsilon_{G}\right)$

The drift flux is plotted against the gas holdup and transitions between regimes correspond to changes in the slope of the curve.

\subsubsection{Liquid-phase mixing time}

Mixing time is determined using a conductimetric method by injecting $2 \mathrm{~mL}$ of a sodium chloride solution at $200 \mathrm{~g} / \mathrm{L}$ as a tracer. This solution is injected at the bottom of the bubble column through one capillary located between two capillaries used for gas sparging and the conductivity sensor is located at position 3 (Fig. 1). The conductivity is measured until a stable value is reached. The response of the conductivity sensor fluctuates due to the passage of bubbles on the sensor.

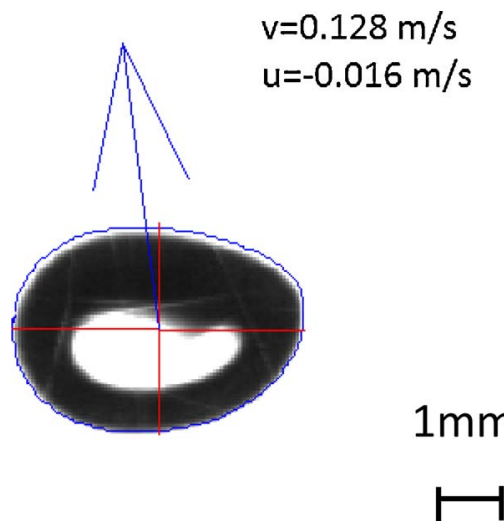

Fig. 2. Example of a single bubble rising in water, detected by shadowgraphy and analyzed by the Dynamic studio software. 
To overcome this problem, the signal is filtered by averaging instantaneous values over 0.5 (when the signal evolves quickly) to $2.5 \mathrm{~s}$ (when the signal approaches steady-state). The filtered signal is used for the estimation of the mixing time, generally defined as the time required to reach complete homogeneity $\pm 5 \%$. In this application, this value is increased to $10 \%$ to have reproducible values. All mixing time experiments are triplicated.

\subsubsection{Gas-liquid mass transfer}

To determine the volumetric mass transfer coefficient, $\mathrm{k}_{\mathrm{L}} \mathrm{a}$, the physical absorption of oxygen by the liquid is characterized. The classical dynamic gassing-out gassing-in method is employed. The experimental procedure consists in the deoxygenation of the reactor with nitrogen bubbling. Then, air is injected by the capillaries and the evolution of the liquid oxygen concentration $v s$ time is measured using an oxygen probe (OXROB10 Pyroscience). Based on the assumption that the liquid phase is perfectly mixed and that the concentration of oxygen in the gas phase remains equal to the one of air (since $\mathrm{O}_{2}$ solubility in the aqueous phase is low), the volumetric mass transfer is deducted from an oxygen mass balance on the whole liquid phase:

$\frac{d C}{d t}=k_{L} a\left(C^{*}-C\right)$

where $\mathrm{C}$ is the instantaneous $\mathrm{O}_{2}$ concentration measured at the probe, and $\mathrm{C}^{*}$ is the $\mathrm{O}_{2}$ saturation concentration. The plot of $\ln \left[\left(\mathrm{C}^{*}-\mathrm{C}\right) /\left(\mathrm{C}^{*}-\right.\right.$ $\mathrm{C}(\mathrm{t}=0))$ ) $v s$ time allows to identify $\mathrm{k}_{\mathrm{L}} \mathrm{a}$ which corresponds to the slope of the curve. Characteristic time of gas-liquid mass transfer $\left(\tau_{\mathrm{O} 2}\right)$ then corresponds to $1 / k_{L} a$ [42].

Here, the mass transfer coefficient of $\mathrm{O}_{2}$ is determined. In PBRs, the $\mathrm{CO}_{2} \mathrm{k}_{\mathrm{L}} \mathrm{a}$ is also to be accounted for. It can be noticed that both values are close since the difference is only due to the difference between the molecular diffusion coefficients of $\mathrm{O}_{2}$ and $\mathrm{CO}_{2}$ in the liquid medium which are close (see paragraph 3.5 ).

\section{Results and discussion}

\subsection{Shadowgraphy of a single bubble}

For the characterization of the rise of a single bubble in the thin-gap column, only one capillary is used and a single bubble is injected at the bottom of the reactor. This bubble rises in the quiescent liquid phase which can be water or an aqueous solution of glycerol at $10 \%$ or $50 \%$ $\mathrm{w} / \mathrm{w}$. The size and the instantaneous velocity of the bubble are measured using shadowgraphy imaging. This measurement is performed at mid height of the column to overcome the influence of the sparger. Due to the confinement and the generated friction forces between the bubble and the walls, it is important to determine the bubble terminal velocity, $U_{\infty}$, in this confined column. In fact, if the terminal velocity is modified, it will influence the bubbles residence time and thus the gas holdup. Experimental values are compared to the correlation of Jamialahmadi et al. [43] established for unconfined bubbles as well as the data of Clift et al. [44] in pure water which have the same trend. Results are reported in Fig. 3a-c respectively for water, 10\% and 50\% $\mathrm{w} / \mathrm{w}$ glycerol solutions. It is found that for an isolated bubble with a diameter lower than $4 \mathrm{~mm}$ rising in quiescent liquid, the terminal velocity is divided by a factor between 1.1 and 1.7 for water in comparison to the correlation of Jamialahmadi, (Fig. 3a), by a factor between 1.4 and 1.9 for a $10 \% \mathrm{w} / \mathrm{w}$ glycerol solution (Fig. 3b) and by a factor between 1.4 and 1.9 for a $50 \%$ w/w glycerol solution (Fig. 3c). For large bubbles, with a diameter higher than $4 \mathrm{~mm}$, the terminal velocity is divided by a factor ranging from 1.6 to 1.9 for water in comparison with Jamialahmadi, by a factor from 1.1 and 1.5 for $10 \% \mathrm{w} / \mathrm{w}$ glycerol solution and from 1.1 to 1.5 for $50 \% \mathrm{w} / \mathrm{w}$ glycerol solution. For these last bubbles, as discussed in paragraph 2.2.1, the equivalent diameter can be overestimated due to a flattening effect.

To summarize, whatever the solution viscosity, the terminal velocities determined experimentally are between 1.1 and 1.9 times lower than those estimated by the correlations given in the literature for unconfined bubbles. Figuero-Espinoza et al. [44] investigated the effect of confinement on the motion of a single clean bubble and showed that the drag coefficient widely increases for oscillating bubbles rising in a confined flat channel. In fact, small bubbles in confined channel undergo wall collisions and consecutive cycles of deceleration and acceleration. These two effects induce an increase of the drag coefficient and thus a decrease in terminal velocities. Such a confinement effect is in agreement with the small terminal velocities observed here. The difference between unconfined and confined configurations is reduced when the diameter of the bubble increases despite the confinement increases (Fig. 3). This result may be explained by the overestimation of the bubble equivalent diameter due to the flattening effect when the diameter exceeds the size of the column-gap ( $4 \mathrm{~mm}$ ).

\subsection{Global gas holdup}

For the three tested liquid phases, the global gas holdup increases with increasing superficial gas velocity (Fig. 4). No significant influence of the liquid phase properties on the global gas holdup can be observed for superficial gas velocities between 0 and $0.01 \mathrm{~m} \mathrm{~s}^{-1}$. As can be seen
a) water
b) $10 \% \mathrm{w} / \mathrm{w}$ glycerol solution
c) $50 \% \mathrm{w} / \mathrm{w}$ glycerol solution
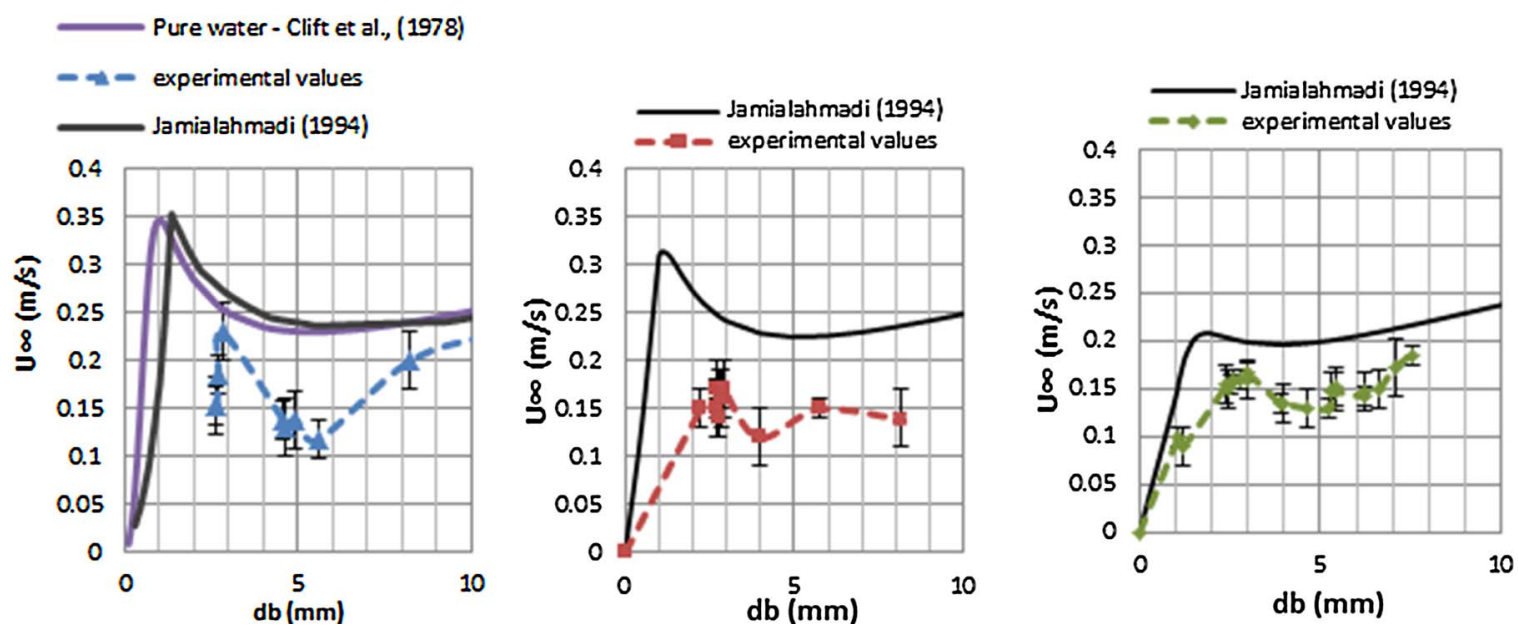

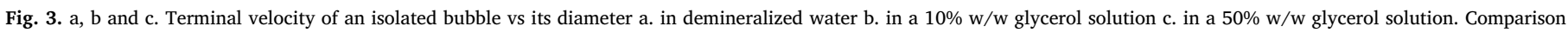
between experiments in a thin-gap column and the correlation of Jamialahmadi et al. [43] for unconfined bubbles and data of Clift et al. in pure water. 


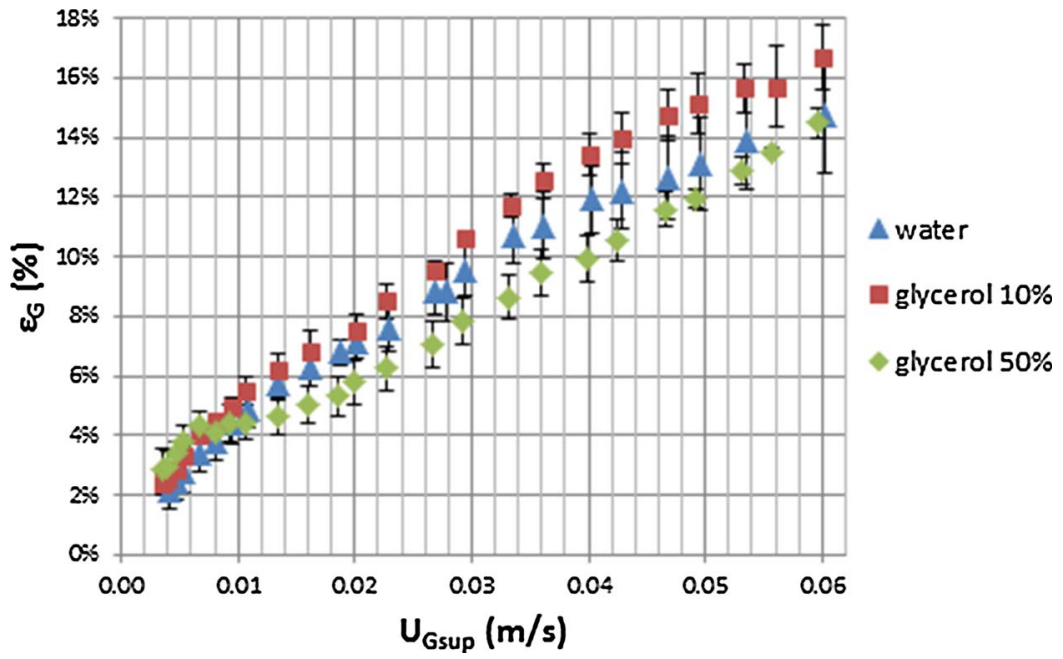

Fig. 4. Evolution of the global gas hold-up with the superficial gas velocity.

in the first part of Table 2, the Sauter diameter is almost the same for the three liquid phases at these low superficial gas velocities. This may be explained by the fact that increasing the glycerol concentration increases the viscosity but also entails a slight decrease in surface tension: antagonist effects appear between a viscosity increase which favors bubble coalescence and the occurrence of larger bubbles with lower residence times on one side, and a surface tension decrease which delays coalescence on the other side $[12,11]$. Furthermore, interaction between bubbles is only weak at such low superficial gas velocities and collision between bubbles is rare which explains that coalescence is negligible. Thus, the observed gas holdup is globally the same for the three liquid phases. Pictures of part of the reactor in Fig. 5a-c show typical bubble shapes and sizes for a swarm of bubbles in ascension in the three liquid phases respectively water, $10 \% \mathrm{w} / \mathrm{w}$ glycerol solution

Table 2

Bubble size and velocity distributions characteristics for the homogeneous regime (one single bubble class) and for the transition regime (5 bubble classes).

\begin{tabular}{|c|c|c|c|c|c|c|c|c|}
\hline \multicolumn{9}{|c|}{ Homogeneous Regime } \\
\hline Fluids & \multicolumn{2}{|c|}{$\begin{array}{l}\text { number } \\
\text { of } \\
\text { bubbles }\end{array}$} & \multicolumn{2}{|r|}{$\begin{array}{l}\mathrm{U}_{\mathrm{Gsup}} \\
\left(\mathrm{m} \mathrm{s}^{-1}\right)\end{array}$} & \multicolumn{2}{|l|}{$\mathrm{d}_{32}(\mathrm{~mm})$} & $\begin{array}{l}\text { Standard } \\
\text { deviation }\end{array}$ & $\begin{array}{l}\text { Velocity of } \\
\text { swarm of } \\
\text { bubbles } \\
\left(\mathrm{m} \mathrm{s}^{-1}\right)\end{array}$ \\
\hline \multirow[t]{3}{*}{ Water } & \multicolumn{2}{|c|}{16050} & \multicolumn{2}{|r|}{0.004} & 4.0 & \multicolumn{2}{|r|}{0.7} & 0.18 \\
\hline & \multicolumn{2}{|c|}{17850} & \multicolumn{2}{|r|}{0.005} & 4.3 & \multicolumn{2}{|r|}{0.9} & 0.18 \\
\hline & \multicolumn{2}{|c|}{14181} & \multicolumn{2}{|r|}{0.007} & 5.5 & \multicolumn{2}{|r|}{1.3} & 0.19 \\
\hline $10 \% \mathrm{w} / \mathrm{w}$ & \multicolumn{2}{|c|}{16285} & \multicolumn{2}{|r|}{0.004} & 3.9 & \multicolumn{2}{|r|}{0.7} & 0.18 \\
\hline glycerol & \multicolumn{2}{|c|}{17160} & \multicolumn{2}{|r|}{0.005} & 4.0 & \multicolumn{2}{|r|}{0.7} & 0.18 \\
\hline solution & \multicolumn{2}{|c|}{12314} & \multicolumn{2}{|r|}{0.007} & 5.0 & & 1.1 & 0.19 \\
\hline $50 \% \mathrm{w} / \mathrm{w}$ & 17938 & & & 0.004 & 3.1 & & 0.5 & 0.17 \\
\hline glycerol & 26919 & & & 0.005 & 3.2 & & 0.5 & 0.15 \\
\hline Transition Regime & $=0.013 \mathrm{~m} \mathrm{~s}^{-}$ & & & & & & & \\
\hline Fluids & $\mathrm{d}$ class $(\mathrm{mm})$ & nb of bubbles & $\mathrm{d}_{32}(\mathrm{~mm})$ & $\begin{array}{l}\text { Standard } \\
\text { deviation }\end{array}$ & $\begin{array}{l}\text { Velocity of bubble classes } \\
\left(\mathrm{m} \mathrm{s}^{-1}\right)\end{array}$ & $\begin{array}{l}\%(\mathrm{Vol} / \\
\left.\text { Vol }_{\text {Tot }}\right)\end{array}$ & $\begin{array}{l}\text { Volu } \\
\text { swar }\end{array}$ & of the bubble \\
\hline Water & $0 \leq \mathrm{d} \leq 3$ & 5753 & 1.7 & & 0.18 & $2 \%$ & 0.32 & \\
\hline & $3<d \leq 5$ & 6925 & 4.2 & & 0.28 & $24.1 \%$ & & \\
\hline & $5<\mathrm{d} \leq 8$ & 3438 & 6.3 & & 0.29 & $33.9 \%$ & & \\
\hline & $8<d \leq 14$ & 1249 & 10.4 & & 0.36 & $33.2 \%$ & & \\
\hline & $\mathrm{d}>14$ & 103 & 16.0 & & 0.42 & $6.7 \%$ & & \\
\hline & pop. tot. & 17468 & 7.5 & 2.8 & 0.25 & $100 \%$ & & \\
\hline $10 \% \mathrm{w} / \mathrm{w}$ glycerol & $0 \leq \mathrm{d} \leq 3$ & 2103 & 2.1 & & 0.18 & $1 \%$ & 0.28 & \\
\hline solution & $3<d \leq 5$ & 6721 & 4.0 & & 0.22 & $21.5 \%$ & & \\
\hline & $5<\mathrm{d} \leq 8$ & 2812 & 6.4 & & 0.25 & $28.4 \%$ & & \\
\hline & $8<\mathrm{d} \leq 14$ & 1013 & 10.7 & & 0.33 & $28.3 \%$ & & \\
\hline & $d>14$ & 233 & 17.1 & & 0.38 & $16.4 \%$ & & \\
\hline & pop. tot. & 12882 & 8.6 & 2.8 & 0.23 & $100 \%$ & & \\
\hline $50 \% \mathrm{w} / \mathrm{w}$ glycerol & $0 \leq \mathrm{d} \leq 3$ & 2035 & 1.9 & & 0.11 & $2.2 \%$ & 0.35 & \\
\hline solution & $3<d \leq 5$ & 1070 & 4.2 & & 0.22 & $7.9 \%$ & & \\
\hline & $5<\mathrm{d} \leq 8$ & 643 & 6.3 & & 0.24 & $14.5 \%$ & & \\
\hline & $8<\mathrm{d} \leq 14$ & 400 & 10.8 & & 0.33 & $25.6 \%$ & & \\
\hline & $d>14$ & 300 & 20.5 & & 0.42 & $49.8 \%$ & & \\
\hline & pop. tot. & 4448 & 13.2 & 4.2 & 0.20 & $100 \%$ & & \\
\hline
\end{tabular}




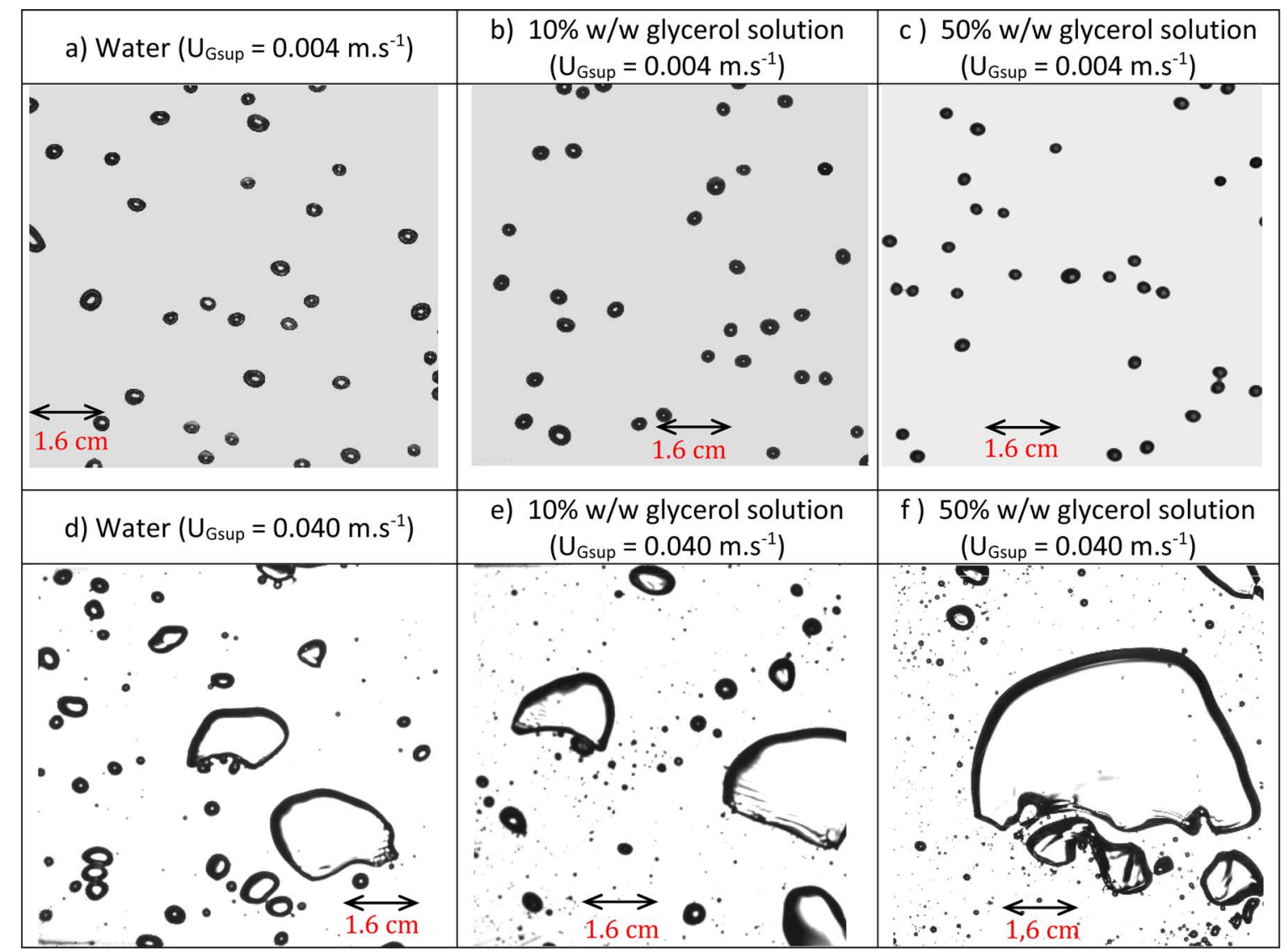

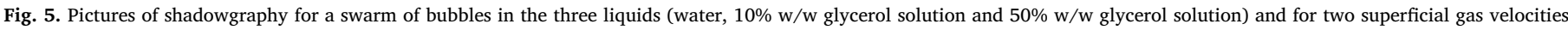
$\left(\mathrm{U}_{\mathrm{Gsup}}=0.004 \mathrm{~m} \mathrm{~s}^{-1}\right.$ and $\left.0.040 \mathrm{~m} \mathrm{~s}^{-1}\right)$.

and $50 \% \mathrm{w} / \mathrm{w}$ glycerol solution for a superficial gas velocity of $0.004 \mathrm{~m} \mathrm{~s}^{-1}$. The same type of bubble size distribution can be observed which confirms that gas holdup should be of the same order.

Beyond a superficial gas velocity of $0.01 \mathrm{~ms}^{-1}$, the gas holdup becomes slightly higher in the $10 \% \mathrm{w} / \mathrm{w}$ glycerol solution compared to water, whereas the gas holdup in the $50 \% \mathrm{w} / \mathrm{w}$ glycerol solution is the lowest. It can be observed in Table 2 and in Fig. $5 \mathrm{~d}-\mathrm{f}$ that for such superficial velocities, coalescence and break-up occur significantly, leading to a large distribution of bubble sizes for the three liquid phases. It is also observed that increasing the glycerol concentration increases the Sauter diameter, $\mathrm{d}_{32}$, of the bubble population which can be explained by the viscosity increase leading to more intense coalescence. Very small submillimetric bubbles are also observed in the glycerol aqueous solutions when increasing the gas flowrate (Fig. 5e and f): they are created by bubble break-up and they are stabilized by surface tension effect. In water, for a same superficial gas velocity $\left(\mathrm{U}_{\mathrm{Gsup}}=0.040 \mathrm{~m} \mathrm{~s}^{-1}\right.$ ), this type of bubble is not observed (Fig. $5 \mathrm{~d}$ ).

For the $10 \% \mathrm{w} / \mathrm{w}$ solution of glycerol, the Sauter diameter is slightly higher than for water (Table 2), however the gas holdup is slightly higher which could seem contradictory since larger bubbles have lower residence time. In fact, the increase of the Sauter diameter can be explained by the relative importance of the largest bubble class $\left(d_{b}>14 \mathrm{~mm}\right)$ volume fraction which is more important in the $10 \% \mathrm{w} /$ $\mathrm{w}$ glycerol solution $(16.4 \%)$ than in water $(6.7 \%)$. But globally each bubble class rises with lower velocity in the $10 \% \mathrm{w} / \mathrm{w}$ glycerol solution than in water because of viscosity increase. This second effect is predominant and therefore the volume average velocity is globally lower in the $10 \% \mathrm{w} / \mathrm{w}$ glycerol solution than in water, which induces higher residence time: this explains why above a superficial velocity of $0.01 \mathrm{~m} \mathrm{~s}^{-1}$, the gas holdup is higher in the $10 \% \mathrm{w} / \mathrm{w}$ glycerol solution than in water.
For the $50 \% \mathrm{w} / \mathrm{w}$ glycerol solution, a large increase of the largest bubble class diameter is observed together with a significant increase in the volume fraction of this class (Table 2). This large bubble class has a very large velocity because of its size. Globally, the volume average velocity of the bubble swarm is the highest in this $50 \% \mathrm{w} / \mathrm{w}$ glycerol solution, which explains that beyond the homogeneous regime $\left(\mathrm{U}_{\mathrm{Gsup}}>0.01 \mathrm{~m} \mathrm{~s}^{-1}\right)$ the gas holdup is the lowest.

This analysis of bubble sizes and velocities distributions explains why in Fig. 4, for a fixed gas superficial velocity, the gas holdup shows a non-monotonic trend with the liquid viscosity. This dual effect of liquid viscosity is in agreement with the results of some literature papers [46-49] which show an increase of gas holdup with viscosity up to values of 2-3 mPa.s and then a significant decrease of gas holdup for higher viscosities. This confirms the result found in Fig. 4 where the gas holdup for the $10 \% \mathrm{w} / \mathrm{w}$ glycerol solution $\left(\mu=1.5 \mathrm{mPa}^{-1} \mathrm{~s}^{-1}\right)$ is higher than for water and the gas holdup for the $50 \% \mathrm{w} / \mathrm{w}$ glycerol solution $\left(\mu=5.7 \mathrm{mPa} . \mathrm{s}^{-1}\right)$ is lower than for water. In fact, our shadowgraphy results confirm the analysis found in literature [49]: moderate viscosity increase enhances the presence of larger bubbles but also of important drag force and thus lower velocities for a given bubble size can be observed (Table 2), this second effect is predominant in our case for the $10 \% \mathrm{w} / \mathrm{w}$ glycerol solution. When the viscosity increase is more important, the coalescence phenomenon is predominant with a greater number of significantly larger bubbles which have higher velocities, globally, the volume average velocity is higher and the gas holdup is lower: these phenomena are observed for the $50 \% \mathrm{w} / \mathrm{w}$ glycerol solution in our case.

Prediction of gas holdup in confined bubble columns is essential for the proper operation of this type of gas-liquid reactors. In particular, it is interesting to compare gas holdup to the one that would be obtained in conventional bubble columns. Results obtained in the present study 
with water as a liquid phase are compared to the ones obtained by Olmos [23], Vandu [50] and Sharaf [51] in conventional bubble columns in Fig. 6.

In the thin gap column, bubbles are confined; they undergo more wall friction. Indeed, as shown previously, their terminal velocity is lower than the one of bubbles in infinite liquid medium. Therefore, for the lowest gas flowrates $\left(\mathrm{U}_{\mathrm{Gsup}}<0.02 \mathrm{~m} \mathrm{~s}^{-1}\right.$ ), the gas holdup is slightly higher than for classical bubble columns due to a higher residence time.

However, beyond a certain superficial gas velocity (around $0.02 \mathrm{~m} \mathrm{~s}^{-1}$ in the present case), the gas holdup is lower than the one obtained for classical bubble column. This result is due to the fact that in the confined column studied here, interaction between bubbles and wake effect are increased. The transition regime and heterogeneous regime appear at lower superficial gas velocities than in conventional columns as will be shown in the next paragraph.

\subsection{Flow regimes and transitions between regimes}

As for conventional bubble columns, visual observation of the twophase flow in the confined column allows to distinguish 3 flow regimes: homogeneous, transition and heterogeneous regimes. In the homogeneous regime, a narrow bubble size distribution is observed, coalescence and break-up can be neglected, and bubbles are rising quite independently in the column. During the transition regime, a polydisperse population of bubbles appears, with the largest bubbles gathering in the center of the column in a central bubble plume. For the highest gas flowrates, this flow macrostructure is destroyed which corresponds to the heterogeneous regime.

Transitions between regimes were first determined using the evolution of the global gas holdup $v s$ superficial gas velocity for the three liquid phases. As can be observed in Fig. 7a obtained for water, it is possible to visualize slope breaks in the gas holdup curve as a function of the superficial gas velocity. Indeed, there is a break of slope at $0.01 \mathrm{~m} \mathrm{~s}^{-1}$, corresponding to the transition between the homogeneous and transition regime. Then, there is another break of slope at around $0.044 \mathrm{~m} \mathrm{~s}^{-1}$, corresponding to the transition between transition and heterogeneous regime.

The swarm velocity method developed by Zuber and Findlay [26] is also used to identify regime transitions as presented in Fig. $7 \mathrm{~b}$ for water. The swarm velocity is quite constant during the homogeneous regime (here for a gas superficial velocity less than $0.01 \mathrm{~m} \mathrm{~s}^{-1}$ ). Then, the swarm velocity increases when the transition regime begins. This is due to the presence of bubbles which coalesce to form larger bubbles rising faster in the column. For water and the $10 \% \mathrm{w} / \mathrm{w}$ solution of glycerol

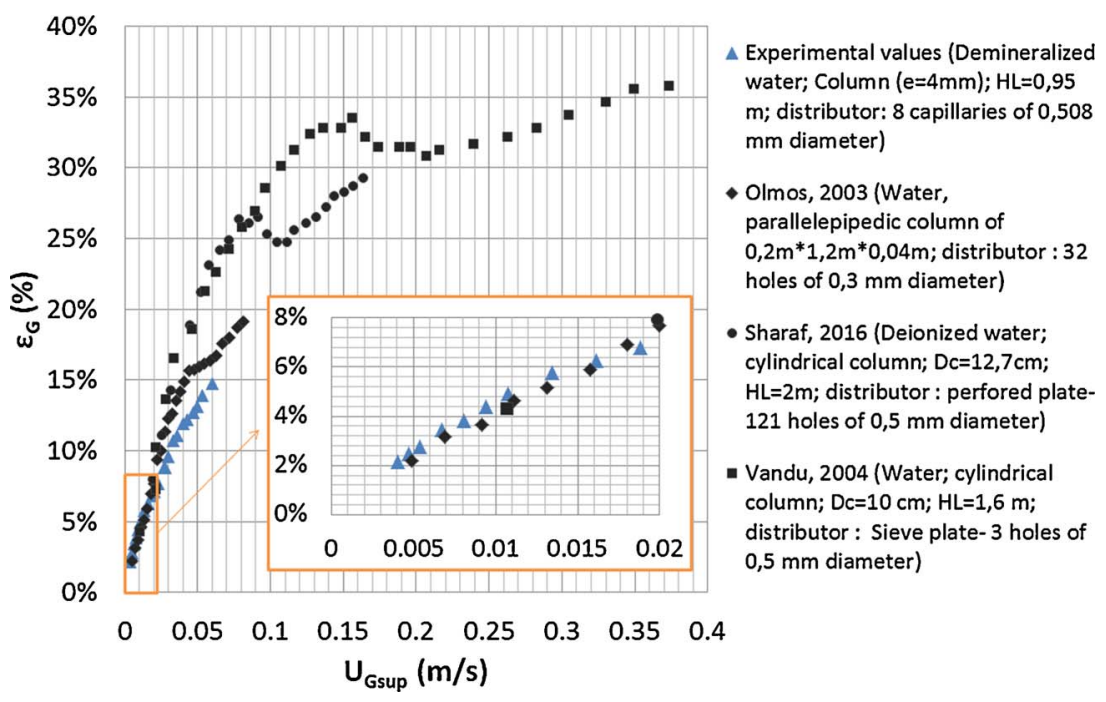

(see Fig. 8), two transition regimes appear, marked by two slope changes between homogeneous and heterogeneous regimes as can be observed in Fig. 7b (first transition at $\mathrm{U}_{\text {Gsup }}=0.010 \mathrm{~m} \mathrm{~s}^{-1}$ and second transition at $\mathrm{U}_{\mathrm{Gsup}}=0.022 \mathrm{~m} \mathrm{~s}^{-1}$ ). In Fig. $7 \mathrm{~b}$, after a gas superficial velocity of $0.044 \mathrm{~m} \mathrm{~s}^{-1}$, the slope changes again which indicates the appearance of the heterogeneous regime.

Two transition regimes have already been described in the literature for parallelepipedic bubble columns, in particular by Olmos [23] for a $4 \mathrm{~cm}$ depth column and by Lin et al. [52] for a $1.27 \mathrm{~cm}$ one. The two transition regimes observed here both present a macroscopic flow structure very similar to the ones observed by Tzeng et al. [53] and Lin et al. [52]. The first transition regime T1 comprises 4 regions: a "central plume region" in the column center composed of bubbles of relatively uniform sizes submitted to a swinging movement. This central region is surrounded by "two fast bubble flow regions" composed of coalesced bubbles or cluster of bubbles. Then, adjacent to these "fast bubble regions", "vertical flow regions" are observed, composed of descending vortices. Finally, near the sidewalls a "descending flow region" takes place where the liquid flows downward. The second transition regime $\mathrm{T} 2$ is only composed of 3 regions since at higher gas flowrates, the two fast bubble flow regions merge together to form a central fast bubble region surrounded by the vertical flow regions and the descending flow regions. These flow macrostructures disappear in the heterogeneous regime.

The drift-flux method developed by Wallis [28] is also used: the drift flux is plotted $v s$ the gas holdup and, as for other methods, changes in the curve slope indicate regime transitions as shown in Fig. 7c for water. In this case, the transition between homogeneous and transition regime appears at gas holdup of $5.6 \%$ which corresponds to a superficial gas velocity of $0.013 \mathrm{~m} \mathrm{~s}^{-1}$ and the transition between transition and heterogeneous regimes appears at gas holdup of $12.2 \%$ which corresponds to a superficial gas velocity of $0.044 \mathrm{~m} \mathrm{~s}^{-1}$.

The transitions between regimes are determined by the abovementioned three methods for the three liquid phases. Only one transition regime has been obtained for the $50 \% \mathrm{w} / \mathrm{w}$ glycerol solution. Table 3 summarizes the results obtained for all fluids and methods; transitions obtained by visual observation are also reported. As can be noticed, when the viscosity of the fluid increases, the tendency to coalesce increases which favors the appearance of the transition and heterogeneous regimes at lower $\mathrm{U}_{\mathrm{Gsup}}$.

One important conclusion is that regime transitions appear for much lower superficial gas velocities in the confined bubble column than in a conventional one. In comparison, in the parallelepipedic column studied by Olmos [23], for air and water, the transition regime appears at $0.03 \mathrm{~m} \mathrm{~s}^{-1}$ against $0.01 \mathrm{~m} \mathrm{~s}^{-1}$ in the present case, and the

Fig. 6. Comparison of gas hold-up obtained in the thin-gap bubble column for water with literature data for conventional bubble columns: Olmos [23], Vandu [45] and Sharaf [46] where $D_{c}$ is the column diameter, $\mathrm{H}_{\mathrm{L}}$ the liquid height and e the thickness. 


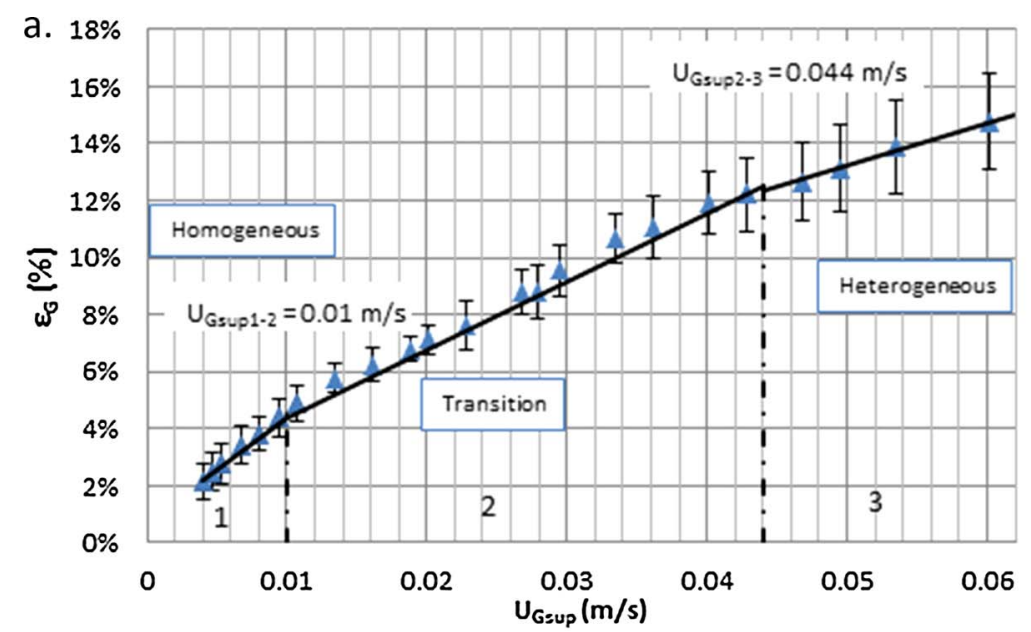

Fig. 7. a, b and c. Determination of regime transitions for water by three methods: a. The first method: $\varepsilon_{\mathrm{G}}=\mathrm{f}\left(\mathrm{U}_{\mathrm{Gsup}}\right)$; $\mathrm{b}$. The swarm velocity method: Uswarm $=\mathrm{f}\left(\mathrm{U}_{\mathrm{Gsup}}\right)$ and $\mathrm{c}$. The drift flux method: $<\mathrm{j}_{\mathrm{GL}}>=\mathrm{f}\left(\mathrm{U}_{\mathrm{Gsup}}\right)$.
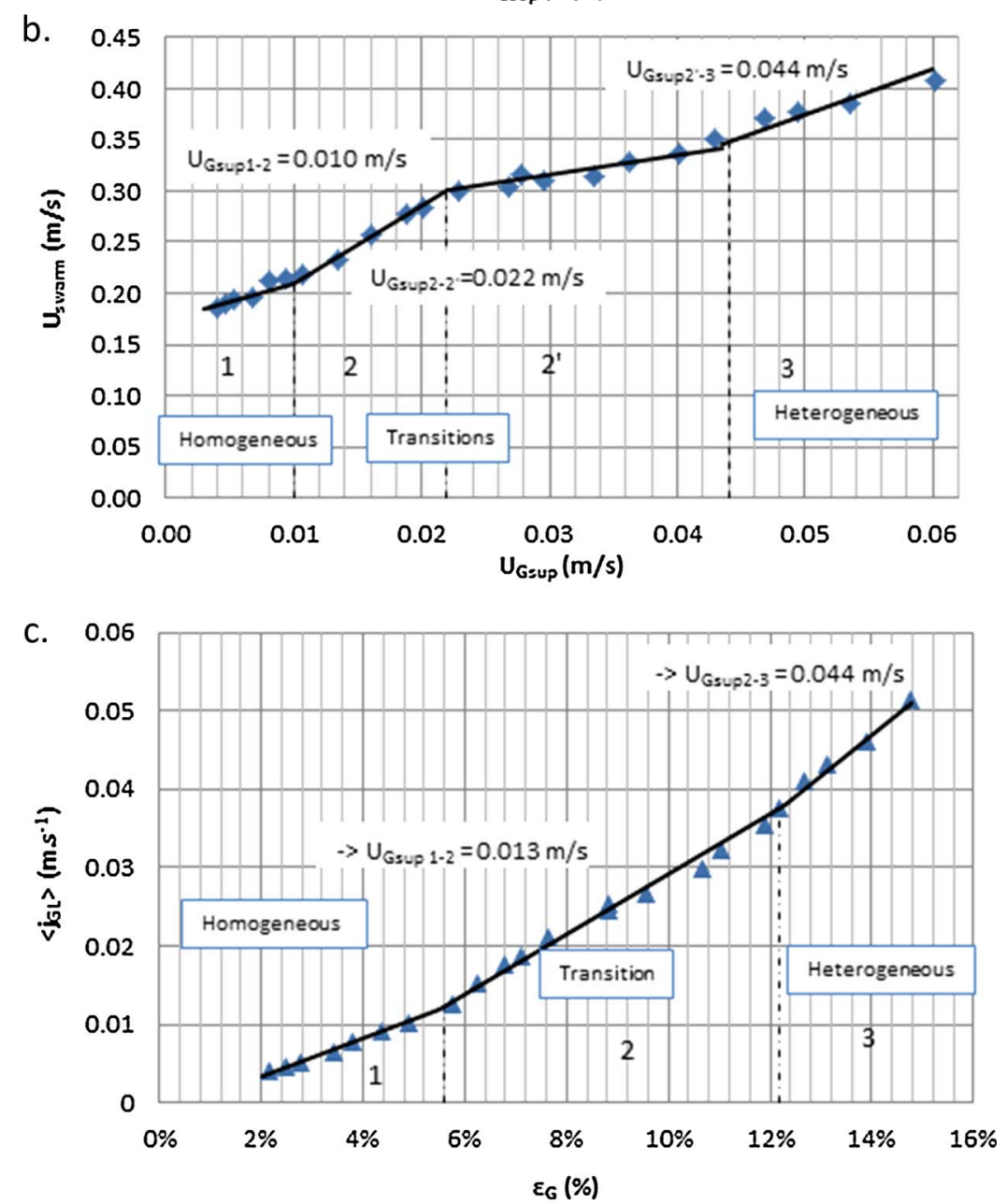

heterogeneous regime appears at $0.065 \mathrm{~m} \mathrm{~s}^{-1}$ against $0.044 \mathrm{~m} \mathrm{~s}^{-1}$ here. For PBRs, an important consequence is that, if it is desired to operate in homogeneous regime, the superficial gas velocity will be limited which will also limit the accessible gas holdup.

In the homogeneous and heterogeneous regimes, the global gas holdup of bubble columns is often correlated to the gas superficial velocity with a power law:

$\varepsilon_{G} \propto U_{G s u p}{ }^{n}$

The value of the parameter " $n$ " depends on the flow regime. In conventional bubble columns, for the homogeneous regime, its value varies from 0.7 to 1 [12] and values higher than 1 are obtained with sintered gas spargers [12]; for the heterogeneous regime, $\mathrm{n}$ is lower and values from 0.4 to 0.7 are encountered [12], [54,55]. The values of $n$ obtained for the three tested liquid phases for confined bubble column are summarized in Table 4: they are in the same range as for conventional columns, with a lower value in the heterogeneous regime, except for the $50 \% \mathrm{w} / \mathrm{w}$ glycerol solution. For this last liquid phase, the variation is quasi-linear in both homogeneous and heterogeneous regimes, but with a much lower slope in heterogeneous regime.

\subsection{Mixing time}

The mixing time is determined for superficial gas velocities from 


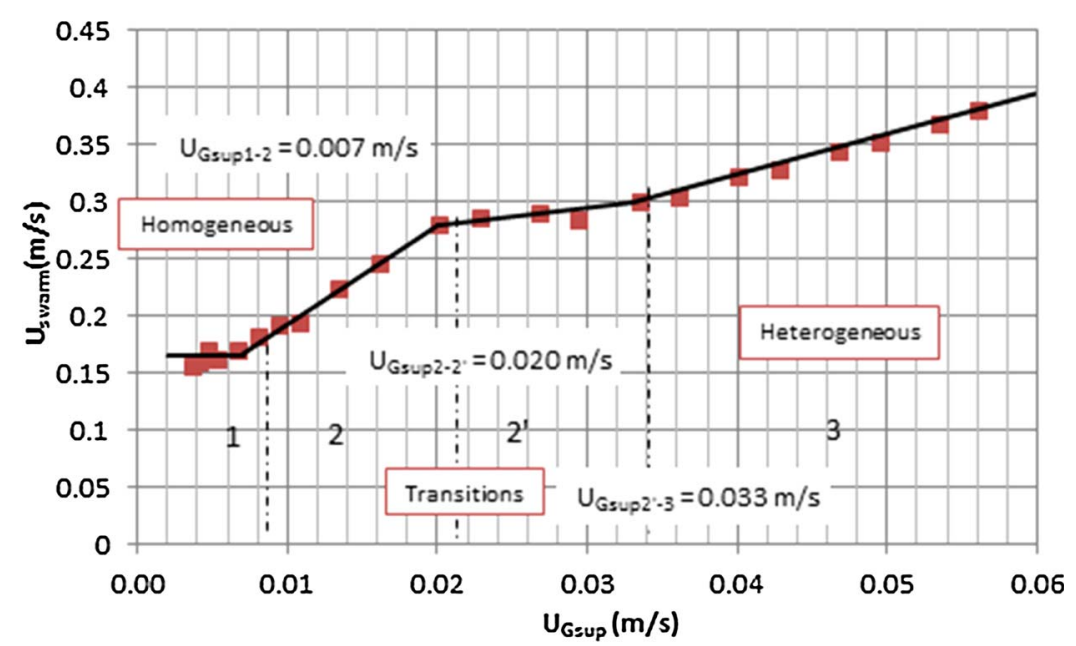

Fig. 8. Determination of regime transitions for the $10 \% \mathrm{w} / \mathrm{w}$ glycerol solution by the swarm velocity method: Uswarm $=f\left(U_{G s u p}\right)$. (1) homogeneous regime; (2) transition regime $1 ;\left(2^{\prime}\right)$ transition regime 2 ; (3) heterogeneous regime.
Table 3

Summary of regime transition results. $\mathrm{U}_{\mathrm{Gsup} 1-2}$ transition superficial gas velocity between the homogeneous and the first transition regime; $\mathrm{U}_{\mathrm{Gsup} 2-2^{\prime}}$ between the first transition and second transition regimes and $\mathrm{U}_{\mathrm{Gsup}^{\prime}-3}$ between the second transition and heterogeneous regimes.

\begin{tabular}{lllll}
\hline Fluids & Methods & $\begin{array}{l}\mathrm{U}_{\mathrm{Gsup1}-2} \\
\left(\mathrm{~m} \mathrm{~s}^{-1}\right)\end{array}$ & $\begin{array}{l}\mathrm{U}_{\mathrm{Gsup} 2-2^{\prime}} \\
\left(\mathrm{m} \mathrm{s}^{-1}\right)\end{array}$ & $\begin{array}{l}\mathrm{U}_{\mathrm{Gsup}^{\prime}-3} \\
\left(\mathrm{~m} \mathrm{~s}^{-1}\right)\end{array}$ \\
\hline \multirow{2}{*}{ Water } & $\varepsilon_{\mathrm{G}}=\mathrm{f}\left(\mathrm{U}_{\mathrm{Gsup}}\right)$ & 0.010 & & 0.044 \\
& $\mathrm{U}_{\text {swarm }}=\mathrm{f}\left(\mathrm{U}_{\mathrm{Gsup}}\right)$ & 0.010 & 0.022 & 0.044 \\
& $<\mathrm{j}_{\mathrm{GL}}>=\mathrm{f}\left(\varepsilon_{\mathrm{G})}\right)$ & 0.013 & & 0.044 \\
& Visual & 0.009 & 0.020 & 0.044 \\
& Mean & 0.011 & 0.021 & 0.044 \\
$10 \%$ w/w glycerol & $\varepsilon_{\mathrm{G}}=\mathrm{f}\left(\mathrm{U}_{\mathrm{Gsup}}\right)$ & 0.009 & 0.020 & 0.033 \\
solution & $\mathrm{U}_{\text {swarm }}=\mathrm{f}\left(\mathrm{U}_{\mathrm{Gsup}}\right)$ & 0.007 & 0.020 & 0.033 \\
& $<\mathrm{j}_{\mathrm{GL}}>=\mathrm{f}\left(\varepsilon_{\mathrm{G}}\right)$ & 0.010 & 0.019 & 0.033 \\
& Visual & 0.008 & 0.018 & 0.033 \\
& Mean & 0.009 & 0.019 & 0.033 \\
$50 \%$ w/w glycerol & $\varepsilon_{\mathrm{G}}=\mathrm{f}\left(\mathrm{U}_{\mathrm{Gsup}}\right)$ & 0.006 & & 0.017 \\
solution & $\mathrm{U}_{\text {swarm }}=\mathrm{f}\left(\mathrm{U}_{\mathrm{Gsup}}\right)$ & 0.006 & & 0.018 \\
& $<\mathrm{j}_{\mathrm{GL}}>=\mathrm{f}\left(\varepsilon_{\mathrm{G}}\right)$ & 0.005 & & 0.019 \\
& Visual & 0.007 & & 0.016 \\
& Mean & 0.006 & & 0.018 \\
\hline
\end{tabular}

Table 4

Correlation for global gas retention $\varepsilon_{\mathrm{G}} \propto \mathrm{U}_{\mathrm{G}}{ }^{\mathrm{n}}$, $\mathrm{n}$ values in the thin-gap bubble column.

\begin{tabular}{llll}
\hline Values of $\mathrm{n}$ & Water & $\begin{array}{l}10 \% \mathrm{w} / \mathrm{w} \text { glycerol } \\
\text { solution }\end{array}$ & $\begin{array}{l}50 \% \mathrm{w} / \mathrm{w} \text { glycerol } \\
\text { solution }\end{array}$ \\
\hline Homogeneous & 0.83 & 0.80 & 0.74 \\
Heterogeneous & 0.59 & 0.57 & 0.79 \\
\hline
\end{tabular}

$0.004 \mathrm{~m} \mathrm{~s}^{-1}$ to $0.056 \mathrm{~m} \mathrm{~s}^{-1}$ for the three solutions (Fig. 9). It has been measured for only one tracer injection position (at the center of the bottom) and one probe position p3 (Fig. 1). Experiments were triplicated. Values of mixing time between a few seconds ( $5 \mathrm{~s})$ and more than $200 \mathrm{~s}$ are observed. Mixing time decreases very quickly with the superficial gas velocity. For water and the $10 \% \mathrm{w} / \mathrm{w}$ glycerol solution, it diminishes rapidly during the homogeneous regime $\left(\mathrm{U}_{\mathrm{Gsup}}<0.10 \mathrm{~m} \mathrm{~s}^{-1}\right)$ and then is quite constant for higher values of $\mathrm{U}_{\text {Gsup. }}$ For the $50 \% \mathrm{w} / \mathrm{w}$ glycerol solution, the important decrease is observed during the homogeneous and transition regimes and then the mixing time diminishes very slowly. These results indicate that mixing is quite poor at low gas flowrates, especially during the homogeneous regime with values up to 10 times higher than those observed in the heterogeneous regime. In the context of PBRs, consequences could be observed on substrate gradients which could be harmful to the culture and lead to yield reductions if the thin-gap PBR is operated in homogeneous regime. Concerning the liquid viscosity, no significant difference between water and glycerol at $10 \% \mathrm{w} / \mathrm{w}$ is observed, but with glycerol at $50 \% \mathrm{w} / \mathrm{w}$, the influence of viscosity is important, especially at low values of $\mathrm{U}_{\mathrm{Gsup}}$, since when $\mathrm{U}_{\mathrm{Gsup}}$ is lower than $0.01 \mathrm{~m} \mathrm{~s}^{-1}$, the mixing time is multiplied by 3 or 4 when switching from water to a $50 \% \mathrm{w} / \mathrm{w}$ glycerol solution. Comparison with literature results for conventional bubble columns is not easy since very different values are observed: mixing time depends on the column geometry and size, on the type of sparger, on the superficial gas velocity but it is also strongly influenced by the injection and measurement locations as pointed out by Mc Clure et al. [56]. Nevertheless, it was found for conventional bubble columns that the superficial gas velocity had a limited influence on the mixing time for $\mathrm{U}_{\mathrm{Gsup}}$ values greater than $0.1 \mathrm{~m} \mathrm{~s}^{-1}$ [56]. In the confined column, the same effect is observed since the influence of $\mathrm{U}_{\mathrm{Gsup}}$ seems minimal in the heterogeneous regime. The increase of the mixing time with the viscosity had already been measured for conventional columns by Rahman-Al Ezzi and Najmuldeen [57] and by Pandit and Joshi [58]. Pandi and Joshi also observed the pronounced effect of viscosity at low superficial gas velocity.

\subsection{Gas-liquid mass transfer}

Firstly, it has been verified if the $\mathrm{O}_{2}$ probe position had an effect on the $\mathrm{k}_{\mathrm{L}} \mathrm{a}$ determination with the dynamic method. Thus, different probe positions have been tested (p1, p2, p3 and p5 in Fig. 1) and the $\mathrm{k}_{\mathrm{L}} \mathrm{a}$ was determined by the dynamic method for a superficial gas velocity of $0.007 \mathrm{~m} \mathrm{~s}^{-1}$ with water as a liquid phase. Fig. 10 shows that the signal registered by the probe is very similar for the tested positions and that the determined $\mathrm{k}_{\mathrm{L}}$ a value is the same indicating that perfect mixing is achieved in the measuring area.

In a second time, the global $\mathrm{k}_{\mathrm{L}} \mathrm{a}$ is determined for gas superficial velocity between $0.004 \mathrm{~m} \mathrm{~s}^{-1}$ and $0.06 \mathrm{~m} \mathrm{~s}^{-1}$ and for three solutions (water, 10 and $50 \% \mathrm{w} / \mathrm{w}$ glycerol solutions). Results are presented in Fig. 11. It must be noticed that for the first $\mathrm{U}_{\mathrm{Gsup}}$ value with water and the $10 \% \mathrm{w} / \mathrm{w}$ glycerol solution and for the first three $\mathrm{U}_{\mathrm{Gsup}}$ values of the curve of glycerol at $50 \%$ (Fig. 9), the mixing time is lower than the transfer characteristic time $\left(1 / \mathrm{k}_{\mathrm{L}} \mathrm{a}\right)$ calculated from Fig. 11 but not 10 times lower. Therefore, in this case the hypothesis of a perfectly mixed reactor could possibly be challenged.

It can be observed that for a given liquid phase, $\mathrm{k}_{\mathrm{L}} \mathrm{a}$ increases with the superficial gas velocity, and that for a given superficial gas velocity, it decreases when the viscosity of the fluid increases (Fig. 11). Influence of viscosity is particularly significant for the $50 \% \mathrm{w} / \mathrm{w}$ solution of glycerol: at superficial gas velocities higher than $0.01 \mathrm{~m} \mathrm{~s}^{-1}$, the $\mathrm{k}_{\mathrm{L}} \mathrm{a}$ in the $50 \% \mathrm{w} / \mathrm{w}$ glycerol solution is divided by a factor two compared to its value in water. In fact, a viscosity increase entails more coalescence thus a lower interfacial area $a$, besides globally the flow speed is lower 


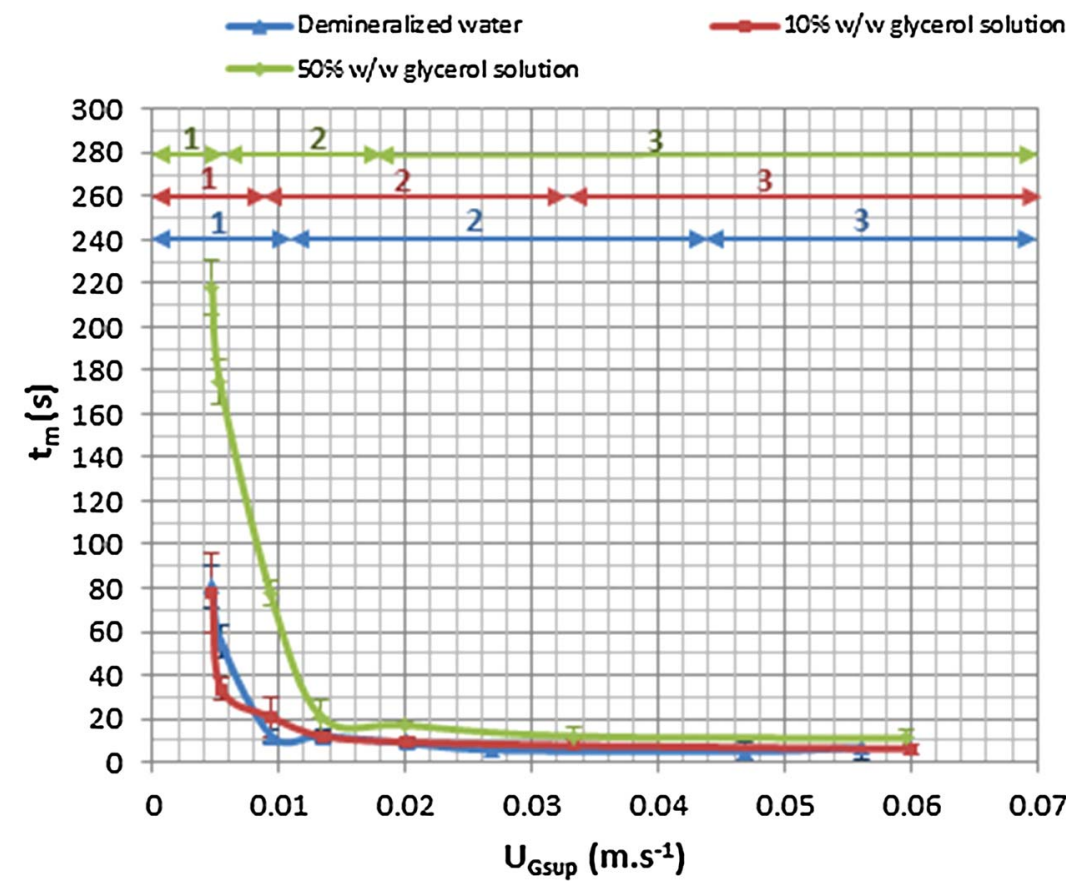

Fig. 9. Evolution of the mixing time with the superficial gas velocity for three liquid phases. (1) homogeneous regime; (2) transition regime; (3) heterogeneous regime.

with lower surface renewal and lower value of $\mathrm{k}_{\mathrm{L}}$.

Another important result is that, compared to conventional bubble columns, the $\mathrm{k}_{\mathrm{L}} \mathrm{a}$ value can be significantly decreased as illustrated in Fig. 12 which compares $\mathrm{k}_{\mathrm{L}}$ a values in the confined column to the results of Koide [36] in a classical bubble column $\left(D_{c}=0.14 \mathrm{~m}\right.$ and $\mathrm{H}_{\mathrm{L}}=1.54 \mathrm{~m}$ ) for water and a $50 \% \mathrm{w} / \mathrm{w}$ glycerol solution.

For instance, in water at a superficial velocity of $0.02 \mathrm{~m} \mathrm{~s}^{-1}$, the gas-liquid mass transfer is almost twice lower than in a classical bubble column. This can be explained by the lower terminal velocities of bubbles encountered in the confined situation; in fact, Higbie's penetration model links gas-liquid mass transfer $\left(\mathrm{k}_{\mathrm{L}}\right)$ to the exposure time $\left(t_{\exp }\right)$ between a liquid element and a gas bubble as described by the following equation:

$k_{L}=2^{*} \sqrt{\frac{D_{L}}{\pi^{*} t_{\exp }}}$

where, $\mathrm{D}_{\mathrm{L}}$ is the diffusion coefficient. In the confined bubble column, terminal velocity of bubbles is lower than in classical bubble columns (Fig. 3), thus, the exposure time is higher, which decreases the gasliquid mass transfer. An opposite effect of confinement on gas-liquid transfer has been observed by Roudet et al. [31] in $1 \mathrm{~mm}$-gap bubble column. In fact, in their case, bubbles are strongly deformed and the presence of a film between the flattened bubble and the walls intensifies transfers. In the present case, the gap has a $4 \mathrm{~mm}$ thickness and most bubbles are only slowed down compared to an infinite medium but no film as observed by Roudet et al. [31] takes place between the bubbles and the walls to enhance transfer. Larger flattened bubbles can be observed at higher $\mathrm{U}_{\mathrm{Gsup}}$ (in the transition and heterogeneous regimes) but due to their important size they present a low superficial area and contribute only moderately to $\mathrm{k}_{\mathrm{L}} \mathrm{a}$.

Concerning the gas-liquid transfer, two issues must be avoided in order to guarantee that microalgal growth will not be limited: oxygen accumulation which could cause inhibition, and low inorganic carbon concentration in the liquid phase which could entail carbon limitation. An analysis of the potentially transferred fluxes will be carried out with the lowest value of $\mathrm{k}_{\mathrm{L}}$ a obtained here. Following the approach of Loubière et al. [59], stationary mass balances on $\mathrm{CO}_{2}$ and $\mathrm{O}_{2}$ lead to:

$N_{\mathrm{CO} 2}=P_{\mathrm{CO} 2}$

and,

$N_{O 2}=P_{O 2}$

where, $\mathrm{N}_{\mathrm{O} 2}$ and $\mathrm{N}_{\mathrm{CO} 2}$ are respectively, the oxygen and carbon dioxide mass transfer rate; $\mathrm{P}_{\mathrm{CO} 2}$, the carbon dioxide volumetric consumption,

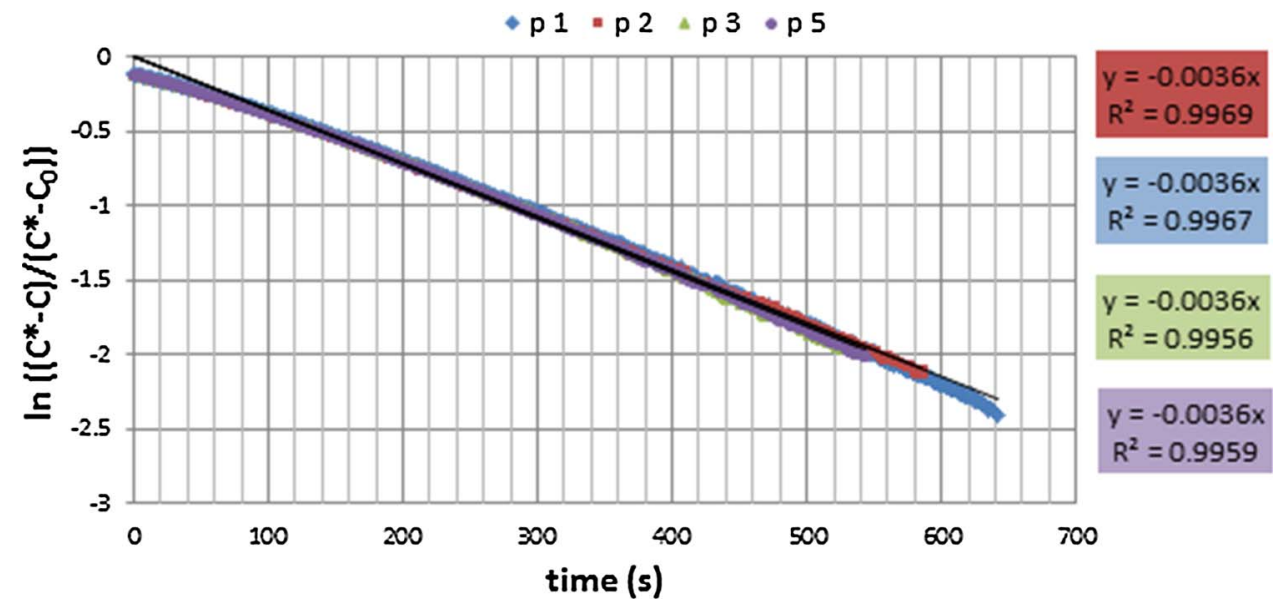

Fig. 10. $\mathrm{k}_{\mathrm{L}}$ a determination for water at a superficial gas velocity of $0.007 \mathrm{~m} \mathrm{~s}^{-1}$ and for different positions of the $\mathrm{O}_{2}$ probe. 


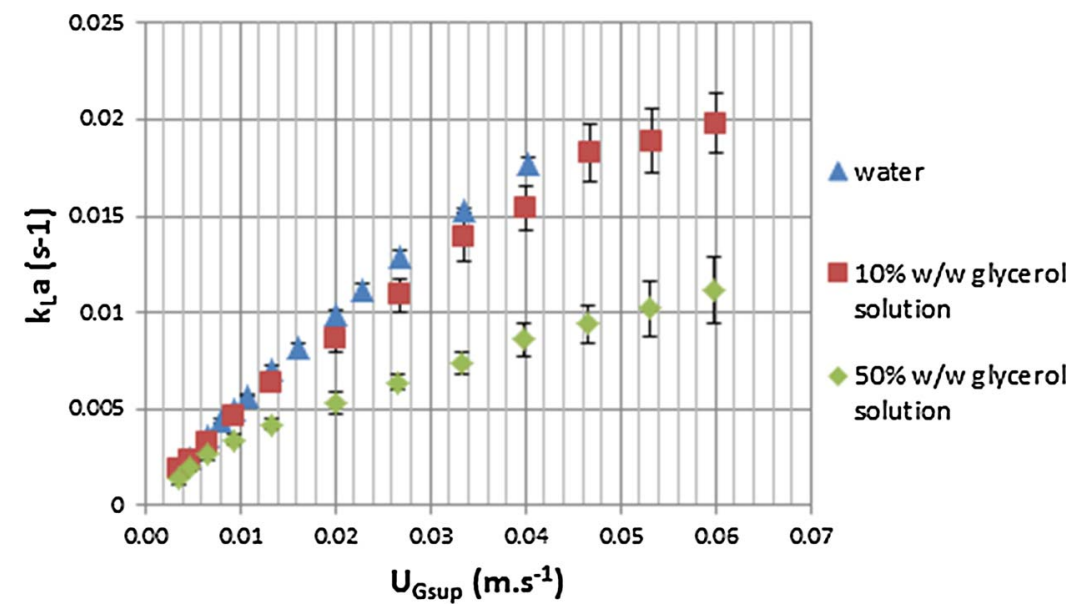

Fig. 11. Evolution of the global gas-liquid mass transfer coefficient $k_{\mathrm{L}} \mathrm{a}$ with the superficial gas velocity for three liquid phases.

and $\mathrm{P}_{\mathrm{O} 2}$, the oxygen volumetric productivity. Oxygen production $\left(\mathrm{P}_{\mathrm{O} 2}\right)$ and carbon dioxide consumption $\left(\mathrm{P}_{\mathrm{CO} 2}\right)$ are proportional to the volumetric productivity $\left(\mathrm{P}_{\mathrm{X}}\right)$ :

$P_{\mathrm{CO} 2}=\frac{1}{Y_{X / \mathrm{CO} 2}} \cdot P_{X}$

$P_{O 2}=Y_{O 2 / X} \cdot P_{X}$

where, $\mathrm{Y}_{\mathrm{X} / \mathrm{CO} 2}$ and $\mathrm{Y}_{\mathrm{O} 2 / \mathrm{X}}$ are respectively the specific yield of biomass production and the specific yield of oxygen production. $\left(\mathrm{Y}_{\mathrm{X}} /\right.$ $\mathrm{CO}_{2}=0.594 \mathrm{~kg}$ of biomass per $\mathrm{kg}$ of carbon dioxide consumed [60] and $\mathrm{Y}_{\mathrm{O} 2 / \mathrm{X}}=2 \mathrm{~kg}$ of oxygen per $\mathrm{kg}$ of biomass [61]). For this intensified photobioreactor of $4 \mathrm{~mm}$ thickness, the volumetric productivity is extrapolated from that found for the Algofilm (C) technology (2 mm thickness) [61], assuming the same surface productivity. So, the volumetric productivity considered here is $5 \mathrm{~kg} \mathrm{~m}^{-3} \mathrm{day}^{-1}$. The transferred fluxes are estimated from the most critical $\mathrm{k}_{\mathrm{L}} \mathrm{a}$ value measured in the present study $\left(\mathrm{k}_{\mathrm{L}} \mathrm{a}=0.0014 \mathrm{~s}^{-1}\right)$ :

$N_{\mathrm{CO} 2}=k_{\mathrm{L}} a_{\left(\mathrm{CO}_{2}\right)}\left(C_{\mathrm{CO} 2}^{*}-C_{\mathrm{CO} 2}\right)$

$N_{O 2}=k_{L} a_{\left(O_{2}\right)}\left(C_{O 2}^{*}-C_{O 2}\right)$

where $\mathrm{k}_{\mathrm{L}} \mathrm{a}_{(\mathrm{O} 2)}$ is determined experimentally (as the lowest value of $0.0014 \mathrm{~s}^{-1}$ ) and $\mathrm{k}_{\mathrm{L}} \mathrm{a}_{(\mathrm{CO} 2)}$ can be deduced using Higbie's model by:

$k_{L} a_{\left(\mathrm{CO}_{2}\right)}=\sqrt{\frac{D_{\mathrm{CO} 2}}{D_{\mathrm{O} 2}}} * k_{L} a_{\left(\mathrm{O}_{2}\right)}=0.909 k_{L} a_{\left(\mathrm{O}_{2}\right)}$

with $\mathrm{D}_{\mathrm{O} 2}=2.41 \times 10^{-9} \mathrm{~m}^{2} \mathrm{~s}^{-1}$ and $\mathrm{D}_{\mathrm{CO} 2}=1.99 \times 10^{-9} \mathrm{~m}^{2} \mathrm{~s}^{-1}$, the

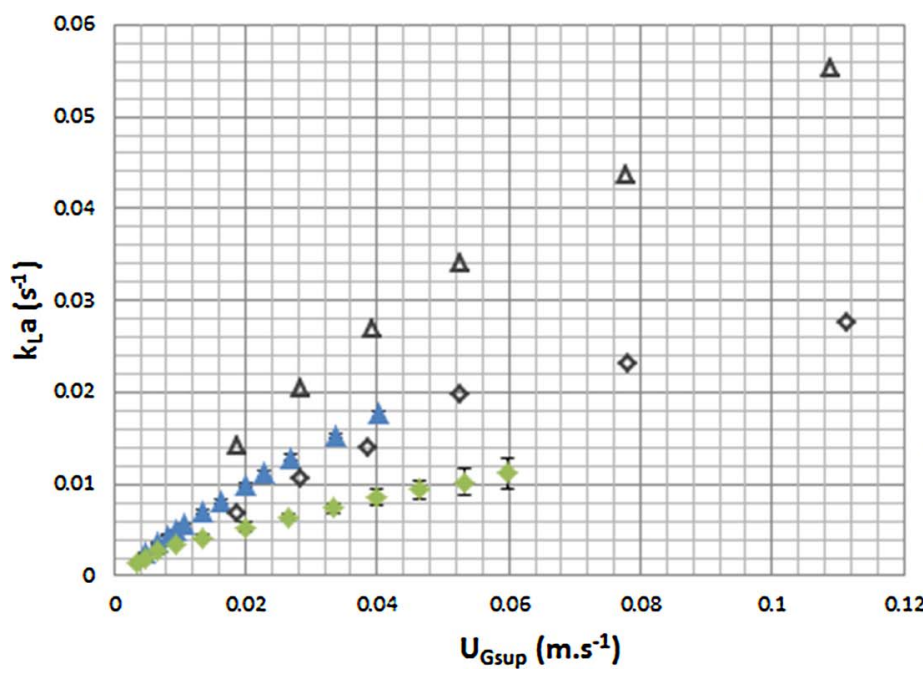

diffusion coefficients in water at $25{ }^{\circ} \mathrm{C}$ [63].

In Eq. (14), $\mathrm{C}_{\mathrm{CO} 2}$ is taken as the minimum concentration of total inorganic carbon to prevent limitation, i.e. $\mathrm{C}_{\mathrm{CO} 2}=10 \mathrm{mM}=0.44 \mathrm{~kg} \mathrm{~m}^{-3}$ for Chlorella Vulgaris according to Le Gouic [62].

Using Eqs. (10), (12) and (14), the required value of carbon dioxide concentration at equilibrium with the gas phase can be determined:

$C_{\mathrm{CO} 2}^{*}=C_{\mathrm{CO} 2}+\frac{P_{\mathrm{CO} 2}}{k_{L} a_{(\mathrm{CO} 2)}}$

Using Henry's law, it is then possible to determine the molar fraction of $\mathrm{CO}_{2}$ in the gas phase $\left(\mathrm{y}_{\mathrm{CO} 2}\right)$ that has to be injected into microalgae culture:

$y_{\mathrm{CO} 2}=\frac{C_{\mathrm{CO} 2}^{*} * \mathrm{H}}{P_{\text {atm }}}=36 \%$

with $\mathrm{H}$ the Henry's constant of $\mathrm{CO}_{2}$ in water $\left(\mathrm{H}=0.703 * 10^{5}\right.$ $\mathrm{Pa} \mathrm{m}^{3} \mathrm{~kg}^{-1}$ [63]) and $\mathrm{P}_{\mathrm{atm}}$, the atmospheric pressure. The calculated $\mathrm{CO}_{2}$ gas fraction being less than $100 \%$, reaching the required inorganic carbon concentration $(10 \mathrm{mM})$ should be feasible, despite some problems such as local acidification near the injection may appear with such high $\mathrm{CO}_{2}$ concentration in the gas phase.

Gas-liquid transfer must also ensure the stripping of the oxygen produced. For the given volumetric productivity, assuming $C_{\mathrm{O} 2}^{*}=8.1 \times 10^{-3} \mathrm{~kg} \mathrm{~m}^{-3}$ at $25^{\circ} \mathrm{C}$ in water, and using Eq. (11), (13) and (15), the oxygen concentration in the liquid medium can be deduced:

$\triangle$ Koide, 1983 [36] (Water, $D C=$ $0.14 \mathrm{~m} ; \mathrm{HL}=1.54 \mathrm{~m}$, mutinozzles of $2 \mathrm{~mm}$ diameter (x12))

$\Delta$ Exper imentalvalues for water: thisstudy

○Koide, 1983 [36] (50\% v/v glycerol solution, $D C=0.14 \mathrm{~m}$; $\mathrm{HL}=1.54 \mathrm{~m}$, multi-nozzles of 2 mm diameter (x12))

- Exper mentalvalues for the $50 \% \mathrm{w} / \mathrm{w}$ glycerol solution: this study
Fig. 12. Comparison between $\mathrm{k}_{\mathrm{L}}$ a values in the thingap bubble column and in a conventional bubble column (Koide) [36]. 
$C_{O 2}=C_{O 2}^{*}+\frac{P_{O 2}}{k_{L} a_{(O 2)}}=9 \times 10^{-2} \mathrm{~kg} \cdot \mathrm{m}^{-3}$

This concentration would be about 11 times higher than the saturation concentration of dissolved oxygen in water at equilibrium with air. Therefore, with such a low $\mathrm{k}_{\mathrm{L}}$ a value, there could be significant $\mathrm{O}_{2}$ accumulation which could entail inhibition of growth of microalgae in our intensified conditions of Chlorella Vulgaris cultivation.

\section{Conclusion}

In bubble columns, the determination of global parameters is of primary importance for scale-up and design purposes, especially when geometry, dimensions, or operating conditions change. In the present study, global characteristics of hydrodynamics and gas-liquid transfer in 2D column with a $4 \mathrm{~mm}$ thickness were carried out with the objective to employ this new equipment in microalgae cultivation. This type of bubble column is completely original since the thickness of the reactor is of the same order as the bubble size which leads to a particular twophase hydrodynamics. First experiments consisted in the measurement of the size and the instantaneous velocity of isolated bubbles using shadowgraphy imaging and showed that the terminal velocities are between 1.1 and 1.9 times lower than those encountered in the literature for unconfined bubbles. This will influence the bubbles residence time and thus the gas holdup. Indeed, in homogeneous regime, the gas holdup is slightly higher than for classical unconfined bubble columns due to a higher residence time. The regime characterization, performed using various methods, showed that regime transitions appear for much lower superficial gas velocities in the confined bubble column than in a conventional one. In addition, two transition regimes appear, marked by two slope changes and presenting a macroscopic flow structure very similar to the ones observed for parallelepipedic conventional columns. For PBRs, an important consequence will be that, if it is desired to operate in homogeneous regime, the superficial gas velocity will be limited which will also limit the accessible gas holdup. The mixing time experiments showed that mixing is quite poor at low gas flowrates, especially during the homogeneous regime with values up to 10 times higher than those observed in the heterogeneous regime. An important increase of the mixing time with the viscosity was also observed and is in agreement with the measured values of conventional columns. Carrying out cultures at high concentrations could thus entail concentration gradients. Finally, experiments performed for three solutions showed also that $\mathrm{k}_{\mathrm{L}} \mathrm{a}$ increases with the superficial gas velocity and decreases when the viscosity of the fluid increases, but in all cases the gas-liquid mass transfer is lower than in classical bubble columns. However, even at low superficial gas velocities, the gas-liquid mass transfer should not entail inorganic carbon limitation, provided that the $\mathrm{CO}_{2}$ concentration in the gas phase is sufficient. But a significant dioxygen accumulation in the liquid could appear which could inhibit growth. One solution to this problem could be to inject bubbles with lower diameters using smaller diameter capillaries.

\section{Acknowledgments}

Authors would like to thank ADEME and Région Pays de la Loire for the financial support of Charlène THOBIE's PhD

\section{References}

[1] M. Gross, Z. Wen, Yearlong evaluation of performance and durability of a pilot-scale Revolving Algal Biofilm (RAB) cultivation system, Bioresour. Technol. 171 (2014) 50-58.

[2] E.M. Grima, E.-H. Belarbi, F.G. Acién Fernández, A. Robles Medina, Y. Chisti, Recovery of microalgal biomass and metabolites: process options and economics, Biotechnol. Adv. Vol. 20 (7) (2003) 491-515.

[3] Doucha J., Lívanský K. Process of outdoor thin-layer cultivation of microalgae and blue-green algae and bioreactor for performing the process. Greek Patent 1002924, 1998; USA Patent 5981271, 1999.
[4] F. Le Borgne, Développement d'un Photobioréacteur Solaire Intensifié En Vue De La Production à Grande échelle De Biomasse Microalgale, Université de Nantes, 2011.

[5] A. Souliès, Contribution à l'étude Hydrodynamique Et à La Modélisation Des Photobioréacteurs à Haute Productivité Volumique, Université de Nantes, 2014.

[6] A. Souliès, J. Pruvost, J. Legrand, C. Castelain, T.I. Burghelea, Rheological properties of suspensions of the green microalga Chlorella vulgaris at various volume fractions, Rheol. Acta 52 (2013) 589-605.

[7] K. Loubière, G. Hébrard, Influence of liquid surface tension (surfactants) on bubble formation at rigid and flexible orifices, Chem. Eng. Process. Process Intensif. 43 (11) (2004) 1361-1369.

[8] A.A. Mouza, G.K. Dalakoglou, S.V. Paras, Effect of liquid properties on the performance of bubble column reactors with fine pore spargers, Chem. Eng. Sci. 60 (5) (2005) 1465-1475.

[9] M.C. Ruzicka, J. Drahos, M. Fiavolá, N.H. Thomas, Effect of bubble column dimensions on flow regime transition, Chem. Eng. Sci. 56 (21) (2001) 6117-6124.

[10] A. Sarrafi, M. Jamialahmadi, H. Müller-Steinagen, J.M. Smith, Gas holdup in homogeneous and heterogeneous gas-liquid bubble column reactors, Can. J. Chem. Eng. 77 (1) (1999) 11-21.

[11] M. Simonnet, Etude Expérimentale Du Mouvement De Bulles En Essaim Application à La Simulation Numérique De Colonnes à Bulles, Institut national polytechnique de Lorraine, 2005.

[12] C. Vial, Apport De La mécanique Des Fluides à l'étude Des Contacteurs Gaz/liquide: Expérience Et Simulation Numérique, Institut national polytechnique de Lorraine, 2000.

[13] P.M. Wilkinson, A.P. Spek, L.L. Van Dierendonck, Design parameters estimation for scale-up of high-pressure bubble columns, AIChE J. 38 (4) (1992) 544-554.

[14] R. Krishna, P.M. Wilkinson, L.L. Van Dierendonck, A model for gas holdup in bubble columns incorporating the influence of gas density on flow regime transitions, Chem. Eng. Sci. 46 (10) (1991) 2491-2496.

[15] I.G. Reilly, D.S. Scott, T.J.W. De Bruijn, D. MacIntyre, The role of gas phase momentum in determining gas holdup and hydrodynamic flow regimes in bubble column operations, Can. J. Chem. Eng. 72 (1) (1994) 3-12.

[16] H.M. Letzel, J.C. Schouten, R. Krishna, C.M. van den Bleek, Characterization of regimes and regime transitions in bubble columns by chaos analysis of pressure signals, Chem. Eng. Sci. 52 (24) (1997) 4447-4459.

[17] E. Olmos, C. Gentric, N. Midoux, Numerical description of flow regime transitions in bubble column reactors by a multiple gas phase model, Chem. Eng. Sci. 58 (10) (2003) 2113-2121.

[18] E. Olmos, C. Gentric, C. Vial, G. Wild, N. Midoux, Numerical simulation of multiphase flow in bubble column reactors. Influence of bubble coalescence and breakup, Chem. Eng. Sci. 56 (21) (2001) 6359-6365.

[19] S. Talvy, A. Cockx, A. Liné, Modeling hydrodynamics of gas-liquid airlift reactor, AIChE J. 53 (2) (2007) 335-353.

[20] M. Simonnet, C. Gentric, E. Olmos, N. Midoux, CFD simulation of the flow field in a bubble column reactor: importance of the drag force formulation to describe regime transitions, Chem. Eng. Process. Process Intensif. 47 (9-10) (2008) 1726-1737.

[21] W.-D. Deckwer, Bubble Column Reactors, Wiley, New York, 1991.

[22] R.C. Chen, J. Reese, L.-S. Fan, Flow structure in a three-dimensional bubble column and three-phase fluidized bed, AIChE J. 40 (7) (1994) 1093-1104.

[23] E. Olmos, Etude Expérimentale Et Numérique Des écoulements Gaz-liquide En Colonne à Bulles, Institut national polytechnique de Lorraine, 2002.

[24] J. Zahradnik, M. Fialová, M. Ruzicka, J. Drahos, F. Kastánek, N.H. Thomas, Duality of the gas-liquid flow regimes in bubble column reactors, Chem. Eng. Sci. 52 (21) (1997) 3811-3826.

[25] G. Besagni, F. Inzoli, Influence of internals on counter-current bubble column hydrodynamics: holdup, flow regime transition and local flow properties, Chem. Eng. Sci. 145 (2016) 162-180.

[26] N. Zuber, J.A. Findlay, Average volumetric concentration in two-phase flow systems, J. Heat Transf. 87 (1965) 453-468.

[27] N.N. Clark, J.W. Van Egmond, E.P. Nebiolo, The drift-flux model applied to bubble columns and low velocity flows, Int. J. Multiph. Flow 16 (2) (1990) 261-279.

[28] G.B. Wallis, One-dimensional Two-phase Flow, McGraw-Hill, New York, 1969 (1969).

[29] M. Roudet, A.-M. Billet, F. Risso, V. Roig, PIV with volume lighting in a narrow cell: an efficient method to measure large velocity fields of rapidly varying flows, Exp. Therm. Fluid Sci. 35 (2011) 1030-1037.

[30] V. Roig, M. Roudet, F. Risso, A.-M. Billet, Dynamics of a high-Reynolds-number bubble rising within a thin gap, J. Fluid Mech 707 (2012) 444-466.

[31] M. Roudet, A.-M. Billet, S. Cazin, F. Risso, V. Roig, Experimental investigation of interfacial mass transfer mechanisms for a confined high-reynolds-number bubble rising in a thin gap, AIChE J. 63 (6) (2017) 2394-2408.

[32] E. Bouche, V. Roig, F. Risso, A.-M. Billet, Homogeneous swarm of high-Reynoldsnumber bubbles rising within a thin gap. Part 1. Bubble dynamics, J. Fluid Mech. 704 (2012) 211-231.

[33] J.J. Heijnen, K. Van't Riet, Mass transfer, mixing and heat transfer phenomena in low viscosity bubble column reactor, Chem. Eng. J. 28 (1984) B21-B42.

[34] Artur W. Adamson, Alice P. Gast, Capillarity, Phys. Chem. Surf. (1997) 26-30 (John Wiley \& Sons, Inc).

[35] A. Sánchez Mirón, F. García Camacho, A. Contreras Gómez, E. Molina Grima, Y. Chisti, Bubble-column and airlift photobioreactors for algal culture, AIChE J. 46 (9) (2000) 1872-1887.

[36] K. Koide, H. Sato, S. Iwamoto, Gas holdup and volumetric liquid- phase mass transfer coefficient in bubble column with draught tube and with gas dispersion into annulus, J. Chem. Eng. Jpn. 16 (1983) 407-413.

[37] C.O. Vandu, R. Krishna, Gas holdup and volumetric mass transfer coefficient in a slurry bubble column, Chem. Eng. Technol 26 (7) (2003) 779-782. 
[38] H.M. Letzel, J.C. Schouten, R. Krishna, C.M. van den Bleek, Gas holdup and mass transfer in bubble column reactors operated at elevated pressure, Chem. Eng. Sci 54 (13) (1999) 2237-2246.

[39] M. Jamialahmadi, H. Müuller-Steinhagen, Effect of superficial gas velocity on bubble size, terminal bubble rise velocity and gas hold-up in bubble columns, Dev. Chem. Eng. Miner. Process 1 (1) (1993) 16-31.

[40] B. Gourich, C. Vial, N. El Azher, M. Belhaj Soulami, M. Ziyad, Influence of hydrodynamics and probe response on oxygen mass transfer measurements in a high aspect ratio bubble column reactor: effect of the coalescence behaviour of the liquid phase, Biochem. Eng. J. 39 (1) (2008) 1-14.

[41] B.N. Thorat, J.B. Joshi, Regime transition in bubble columns: experimental and predictions, Exp. Therm. Fluid Sci. 28 (5) (2004) 423-430.

[42] F. Camacho Rubio, A. Sánchez Mirón, M.C. Cerón García, F. García Camacho, E. Molina Grima, Y. Chisti, Mixing in bubble columns: a new approach for characterizing dispersion coefficients, Chem. Eng. Sci. 59 (20) (2004) 4369-4376.

[43] M. Jamialahmadi, C. Branch, H. Müuller-Steinhagen, Terminal bubble rise velocity in liquids », Trans. Inst. Chem. Eng. 72 (A) (1994) 119-122.

[44] R. Clift, J.R. Grace, M.E. Weber, Bubbles, Drops and Particles, Academic Press, New York San Francisco London, 1978, p. 380.

[45] B. Figueroa-Espinoza, R. Zenit, D. Legendre, The effect of confinement on the motion of a single clean bubble, J. Fluid Mech. 616 (2008) 419.

[46] J.Y. Kim, B. Kim, N.-S. Nho, K.-S. Go, W. Kim, J.W. Bae, S.W. Jeong, N. Epstein, D.H. Lee, Gas holdup and hydrodynamic flow regime transition in bubble columns, J. Ind. Eng. Chem. 56 (2017) 450-462.

[47] S.H. Eissa, K. Schügerl, Holdup and backmixing investigations in cocurrent and countercurrent bubble columns, Chem. Eng. Sci. 30 (1975) 1251-1256.

[48] M.C. Ruzicka, J. Drahos, P.C. Mena, J.A. Teixeira, Effect of viscosity on homogeneous-heterogeneous regime transition in bubble columns, Chem. Eng. J. 96 (2003) 15-22.

[49] G. Besagni, F. Inzoli, G. De Guido, L.A. Pellegrini, The dual effect of viscosity on bubble column hydrodynamics, Chem. Eng. Sci. 158 (2017) 509-538.

[50] C. Vandu, R. Krishna, Volumetric mass transfer coefficients in slurry bubble columns operating in the churn-turbulent flow regime, Chem. Eng. Process. Process
Intensif. 43 (8) (2004) 987-995.

[51] S. Sharaf, M. Zednikova, M.C. Ruzicka, B.J. Azzopardi, Global and local hydrodynamics of bubble columns - Effect of gas distributor, Chem. Eng. J. 288 (2016) 489-504.

[52] T.-J. Lin, J. Reese, T. Hong, L.-S. Fan, Quantitative analysis and computation of twodimensional bubble columns, AIChE J. 42 (2) (1996) 301-318.

[53] J.-W. Tzeng, R.C. Chen, L.-S. Fan, Visualization of flow characteristics in a 2-D bubble column and three-phase fluidized bed, AIChE J. 39 (5) (1993) 733-744.

[54] B. Moshtari, E.G. Babakhani, J.S. Moghaddas, Experimental study of gas hold-up and bubble behavior in gas-liquid bubble column, Pet. Coal 51 (1) (2009) 27-32.

[55] Y.T. Shah, B.G. Kelkar, S.P. Godbole, W.-D. Deckwer, Design parameters estimations for bubble column reactors, AIChE J. 28 (3) (1982) 353-379.

[56] D.D. McClure, N. Aboudha, J.M. Kavanagh, D.F. Fletcher, G.W. Barton, Mixing in bubble column reactors: experimental study and CFD modeling, Chem. Eng. J. 264 (2015) 291-301.

[57] A.A. Rahman-Al Ezzi, G.F. Najmuldeena, Gas hold-Up, mixing time and circulation time in internal loop airlift bubble column, Int. J. Eng. Res. Appl. 4 (2014) 286-294.

[58] A.B. Pandit, J.B. Joshi, Mixing in mechanically agitated gas-liquid contactors, bubble columns and modified bubble columns, Chem. Eng. Sci. 38 (8) (1983) 1189-1215.

[59] K. Loubière, E. Olivo, G. Bougaran, J. Pruvost, R. Robert, J. Legrand, A new photobioreactor for continuous microalgal production in hatcheries bases on externalloop airlift and swirling flow, Biotechnol. Bioeng. 102 (2009) 132-147.

[60] X. Gao, B. Kong, R.D. Vigil, Characteristic time scales of mixing, mass transfer and biomass growth in a Taylor vortex algal photobioreactor, Bioresour. Technol. 198 (2015) 283-291.

[61] J. Pruvost, F. Le Borgne, A. Artu, J. Legrand, Development of a thin-film solar photobioreactor with high biomass volumetric productivity (Algofilm(C) based on process intensification principles, Algal Res. 21 (2017) 120-137.

[62] B. Le Gouic, Analyse et optimisation de l'apport de carbone en photobioréacteur, Ecole Centrale de Nantes, 2013.

[63] M. Roustan, Transferts Gaz-liquide Dans Les Procédés De Traitement Des Eaux Et Des Effluents Gazeux, Lavoisier, Paris, 2003, p. 798. 